\title{
O debate Fromm-Marcuse (1955-1956)
}

\section{Matheus Romanetto ${ }^{l}$}

Algumas das mais relevantes tentativas de atualização da concepção marxista da subjetividade deram-se na forma de sínteses ou diálogos entre a obra de Marx e a psicanálise. Desde os esforços de Otto Fenichel e Siegfried Bernfeld, passando pelos primeiros escritos de Wilhelm Reich, por Max Horkheimer e Theodor Adorno, e chegando a nomes contemporâneos como os de Gayle Rubin e Slavoj Žižek, temos hoje já toda uma tradição de autores que - marxistas ou fortemente relacionados a essa corrente de pensamento - admitiram que a compreensão do inconsciente seria um passo fundamental para a continuação da crítica materialista inaugurada por Marx.

Assim como o marxismo, entretanto, também a psicanálise desdobrou-se em correntes distintas ao longo do século passado e isso deixou sua marca sobre a história dos encontros e conflitos entre as duas doutrinas. Os textos cuja tradução apresentamos a seguir são um capítulo importante dessa história. Entre 1955 e 1956, Herbert Marcuse e Erich Fromm travaram um debate nas páginas da revista Dissent - uma publicação socialista sediada nos Estados Unidos, então recém-inaugurada e editada por Irving Howe e Lewis Coser. Antigos colegas no Instituto de Pesquisa Social de Frankfurt, Fromm e Marcuse haviam já por essa época se distanciado: desacordos teóricos e financeiros levaram Fromm a uma ruptura definitiva com o círculo de Frankfurt, então encabeçado por Horkheimer, abrindo alas para a consolidação de

\footnotetext{
${ }^{1}$ Mestrando pelo Programa de Pós-Graduação em Sociologia da Faculdade de Filosofia, Letras e Ciências Humanas da Universidade de São Paulo (PPGSFFLCH, USP). Email: matheus.romanetto@hotmail.com
} 
seu abandono de algumas das premissas da psicanálise freudiana - especialmente a teoria da libido, com sua ênfase sobre as raízes sexuais de variados fenômenos psíquicos. É esta uma das principais fontes do embate entre Fromm e Marcuse: se o primeiro opta por desenvolver uma teoria em que os conceitos de "relação" e "relacionalidade" são centrais, e em que o inconsciente é conceito puramente funcional, Marcuse sustenta que as referências à libido e às demais categorias metapsicológicas de Freud são elementos imprescindíveis para uma crítica psicanalítica da civilização.

O debate com Marcuse viria a cristalizar definitivamente a distância entre Fromm e seu antigo círculo, e terminaria por exercer grande influência sobre a recepção de ambos os autores. A réplica de Fromm, no fundo, não se esgota nos dois textos breves que escreveu entre 1955 e 1956. Se, em Marx's concept of man, de 1961, ele elogiaria ainda o Reason and revolution de Marcuse, no final daquela década, em uma série de textos dispersos, sua crítica ao antigo colega tomaria uma forma mais extensa e consistente. Formulações parciais de sua posição final a esse respeito encontram-se espalhadas entre os livros The revolution of hope, de 1968, The crisis of psychoanalysis, de 1970, e The anatomy of human destructiveness, de 1973, bem como no capítulo póstumo "The alleged radicalism of Herbert Marcuse", publicado em The revision of psychoanalysis, de 1990. Marcuse, por sua vez, amadurece sempre mais sua relação com Freud em "The obsolescence of psychoanalysis", por exemplo -, mas não altera fundamentalmente sua posição com relação a Fromm (cf., por exemplo, "Theory and therapy in Freud"). Deixaremos indicadas, nas referências bibliográficas, as edições desses textos a que a leitora ou o leitor poderá recorrer. Preparamos também uma seleta de artigos e livros que discutem a recepção e a continuação desse debate na literatura secundária - tanto aquela mais favorável a Marcuse quanto aquela mais favorável a Fromm.

No que diz respeito à tradução, vale a pena dar alguns esclarecimentos sobre o procedimento adotado:

a) $\mathrm{O}$ debate é composto por quatro textos em inglês, dois de Marcuse e dois de Fromm. O primeiro texto é de Marcuse, e 
seguem-se a ele três réplicas. Ocorre que uma versão modificada desse artigo foi publicada também em livro, como epílogo ao Eros and civilization de Marcuse, que ainda não havia aparecido à época das edições de 1955 da Dissent. Por isso, utilizamos ambas as cópias - a da revista e a do livro - para preparar a tradução seguinte. $\mathrm{O}$ texto base (aquele que foi lido por Fromm para escrever sua resposta) é o da revista, e por isso fornece o esqueleto principal da versão que apresentamos a seguir. A maioria das modificações que aparecem no livro são de ordem puramente editorial - pequenas correções gramaticais, mudanças na quebra entre parágrafos etc. Mas acontecem também alguns acréscimos substanciais de texto, bem como mudanças significativas de verbos, substantivos e expressões. Sempre que julgamos as modificações semanticamente relevantes, mantivemos as duas versões, indicando entre \{chaves\} a versão do livro. Acréscimos simples ocorrem no corpo do texto, e substituições são indicadas em notas de rodapé.

b) As alterações de ordem editorial na segunda versão do texto foram acolhidas como sugestões, mas não as mantivemos obrigatoriamente. Preservamos em todos os casos a divisão de parágrafos da edição original, na revista, e modificamos os sinais de pontuação no interior dos períodos apenas quando facilitavam a leitura em português (neste caso, tanto nos textos de Marcuse quanto nos de Fromm). Uma peculiaridade da versão original é que Marcuse escreve com letras maiúsculas os nomes das categorias especulativas de Freud, traço que mantivemos em nossa grafia.

c) As citações que ocorrem no corpo da tradução são sempre nossas, e partem dos segmentos em inglês apresentados pelos próprios Fromm e Marcuse. Para todos os textos citados, entretanto, consultamos tanto as edições utilizadas pelos dois autores quanto as versões já existentes delas em português - inclusive a de Eros e civilização, onde encontra-se uma excelente tradução prévia da segunda versão do primeiro texto de Marcuse. A maioria dos livros mencionados no debate já foi vertida ao português, mas nem todos. Tanto no corpo principal do texto quanto nas notas de rodapé, todos os acréscimos e comentários de nossa autoria estão indicados com [colchetes]. 
d) Um caso especial são as citações de Freud e Fromm cujos originais encontram-se em alemão. Desta vez, não apenas contrapusemos as versões em inglês que Fromm e Marcuse mobilizam às respectivas edições brasileiras, mas recorremos também aos originais, fornecendo as passagens correspondentes em notas de rodapé sempre que isso nos pareceu importante. A situação mais complexa é a dos textos de Fromm de 1932 e 1934, "Über Methode und Aufgabe einer analytischen Sozialpsychologie" e "Das sozialpsychologische Bedeutung der Mutterrechtstheorie". Quando Marcuse redigiu sua polêmica, não havia ainda tradução desses artigos para o inglês. Por isso, ele apresenta nas citações o que parecem ser versões de punho próprio a partir do original alemão. Entretanto, apareceu 15 anos mais tarde, em 1970, um par de traduções do próprio Fromm para o inglês, publicado no livro The crisis of psychoanalsyis - e este, sim, foi vertido para o português. Contamos, então, com pelo menos cinco versões das passagens citadas desses dois textos: o original alemão; a versão de Marcuse para o inglês; a versão de Fromm para o inglês; a tradução anterior de Marcuse para o português; a tradução de Fromm para o português. Cotejamos todas essas edições, e apresentamos um comentário às diferenças mais significativas nas notas de rodapé correspondentes, acompanhado do texto alemão. Nos casos mais simples, o procedimento é o mesmo, mas recorremos a comentários sobre as diferentes edições apenas onde pareceram interessantes.

e) Acrescentamos também, em alguns poucos casos sempre entre [colchetes] -, indicações bibliográficas e comentários que podem ajudar a esclarecer as passagens mais alusivas, menos imediatamente compreensíveis do debate. Para não poluir o corpo central do texto e facilitar a comparação entre as várias versões consultadas, concentramos sempre nas notas de rodapé as referências bibliográficas, adequando-as às normas editoriais desta revista. $\mathrm{O}$ que originalmente seriam itálicos aparece aqui como negritos; os itálicos ficaram reservados para expressões em outras línguas. No rodapé, aparecem sempre, em primeiro lugar, as edições inglesas ou norte-americanas citadas pelos próprios Fromm e Marcuse; em seguida, as edições brasileiras e, quando necessário, o original alemão das mesmas fontes. 
f) Fez falta particularmente uma tradução de Psychoanalysis and religion, de Fromm, publicada pela Editora 70, à qual não tivemos acesso. A edição que consultamos, publicada em 1959, tem problemas graves, que discutiremos nas notas rodapé correspondentes. Em alguns casos - sobretudo com os textos de Freud - há mais de uma tradução para o português dos livros citados. Contentamo-nos em cotejar o inglês e o alemão com uma edição, apenas.

g) Por fim, preservamos e traduzimos também uma chamada da revista Dissent que aparece logo antes do primeiro texto, e dá uma pista sobre o contexto da publicação. Acrescentamos, a pedido dos detentores dos direitos autorais de cada texto, as respectivas indicações, sob a forma de notas acompanhando o título de cada texto. Agradecemos especialmente a colaboração gentil dos doutores Rainer Funk, Peter Marcuse e Harold Marcuse, que autorizaram a publicação desta tradução. 


\title{
As implicações sociais do "revisionismo" freudiano" $\{\text { Crítica do revisionismo neofreudiano }\}^{3}$
}

\author{
Herbert Marcuse
}

O artigo seguinte forma um epílogo a um livro que deve aparecer neste outono sob a imprensa da Beacon Press. Intitulado provisoriamente EROS E CIVILIZAÇÃO, o livro do sr. Marcuse lida com algumas das implicações sociais, políticas e culturais da teoria freudiana. Deve-se enfatizar que, no contexto do livro do sr. Marcuse, o artigo impresso abaixo segue a um desenvolvimento completo de suas próprias ideias. Erich Fromm responderá ao artigo controverso do sr. Marcuse em nossa próxima edição. - Os editores [da revista Dissent].

\footnotetext{
2 Tradução de Matheus Romanetto. Com a permissão do executor testamentário do Patrimônio Literário de Herbert Marcuse, Peter Marcuse - cuja permissão se exige para qualquer publicação futura. Material suplementar produzido a partir de obras de Herbert Marcuse não antes publicadas, muito do que agora se encontra nos Arquivos da Universidade Goethe de Frankfurt am Main, está sendo publicado pela Editora Routledge, da Inglaterra, em uma série de seus volumes editada por Douglas Kellner, bem como em uma série alemã editada por Peter-Erwin Jansen e publicada pela Editora zu Klampen, da Alemanha. Todos os direitos para publicações futuras são retidos pelo Patrimônio. [With permission of the Literary Estate of Herbert Marcuse, Peter Marcuse, Executor, whose permission is required for any further publication. Supplementary material from previously unpublished work of Herbert Marcuse, much now in the Archives of the Goethe University in Frankfurt/Main, is being published by Routledge Publishers, England, in a six-volume series edited by Douglas Kellner, and in a German series edited by Peter-Erwin Jansen published by zu Klampen Verlag, Germany. All rights to further publication are retained by the Estate.]

${ }^{3}$ [O título de Marcuse é possível alusão a Karen Horney, que polemizava contra Freud - nos livros citados abaixo - fazendo referência às "implicações culturais" ("cultural implications") de alguns de seus conceitos e teses.]
} 
A psicanálise mudou sua função na cultura intelectual de nosso tempo, em consonância com as transformações sociais fundamentais que ocorreram durante a primeira metade do século. O colapso da era liberal \{e de suas promessas\}, a tendência totalitária que se difunde e os esforços para romper ${ }^{4}$ essa tendência refletem-se na posição da psicanálise. Durante os vinte anos de seu desenvolvimento que antecederam a \{P\}rimeira Guerra Mundial, a psicanálise elaborou os conceitos para a crítica psicológica da conquista mais aclamada da era moderna: o indivíduo. Freud demonstrou que coerção, repressão ${ }^{5}$ e renúncia eram a matéria a partir da qual a "personalidade livre" era fabricada; ele reconheceu a "infelicidade geral" da sociedade como o limite intransponível da cura e da normalidade. A psicanálise era uma teoria radicalmente crítica. Ulteriormente, quando as Europas central e oriental estavam em levante revolucionário, ficou claro em que medida a psicanálise estava ainda comprometida com a sociedade cujos segredos ela revelava. A concepção psicanalítica do homem, com sua crença na imutabilidade básica da natureza humana, apareceu como "reacionária": a teoria freudiana parecia implicar que os ideais humanitários do socialismo eram humanamente inalcançáveis.

As revisões da psicanálise começaram então a ganhar impulso. Poderia ser tentador falar em uma divisão entre uma ala esquerda e uma ala direita. A tentativa mais séria de desenvolver a teoria social crítica implícita em Freud deu-se nos escritos iniciais de Wilhelm Reich. Em sua Irrupção da moral sexual repressiva [Einbruch der Sexualmoral] (1931), ${ }^{6}$ Reich \{orientou a psicanálise

\footnotetext{
${ }^{4}\{$ Contrariar (ou se opor a) [counter-act]\}

5 “Repressão" e "repressivo" são utilizados neste artigo em sentido não técnico, para indicar processos de restrição, coerção e supressão tanto conscientes quanto inconscientes, tanto externos quanto internos.

${ }^{6}$ [Marcuse apresenta apenas o título alemão, sem traduzi-lo nem indicar a edição utilizada. O título que empregamos é o da edição portuguesa: Porto: Escorpião, 1974.]
} 
à relação entre as estruturas social e instintual\}. Ele enfatizou em que medida a repressão sexual era ${ }^{7}$ imposta pelos interesses da dominação e da exploração, e a medida em que esses interesses eram reforçados \{e reproduzidos\} pela repressão sexual. Entretanto, a noção de repressão sexual de Reich permanece indiferenciada; a dinâmica histórica dos instintos sexuais e de sua fusão com os impulsos destrutivos é negligenciada. (Reich rejeita a hipótese de Freud do Instinto de Morte e toda a dimensão profunda revelada na metapsicologia tardia de Freud). Consequentemente, a liberação sexual per se torna-se, para Reich, a panaceia para as mazelas individuais e sociais. O problema da sublimação é minimizado; não se faz distinção essencial alguma entre sublimação repressiva e não-repressiva, e o progresso na liberdade aparece como mera liberação da sexualidade. As intuições [insights] sociológicas críticas contidas nos escritos iniciais de Reich ficam assim detidas; tornase predominante um primitivismo avassalador, que pressagia os passatempos selvagens e fantásticos dos anos posteriores de Reich.

$\mathrm{Na}$ "ala direita" da psicanálise, a psicologia de Carl Jung tornou-se rapidamente uma pseudomitologia obscurantista. ${ }^{8}$ $\mathrm{O}$ "centro" do revisionismo tomou forma nas escolas culturais e interpessoais - a tendência mais popular da psicanálise hoje. Nós tentaremos mostrar que nessas escolas a teoria psicanalítica converte-se em ideologia: a "personalidade" e suas potencialidades criativas são ressuscitadas face a uma realidade que eliminou quase completamente as condições para a personalidade e para sua realização. Freud reconheceu o trabalho da repressão nos valores mais elevados da civilização ocidental: eles pressupõem e perpetuam a não-liberdade e o sofrimento. As escolas neofreudianas propagam ${ }^{9}$ esses mesmos valores como cura contra a não-liberdade e o sofrimento - como o triunfo sobre a repressão. Esse feito intelectual é realizado por meio do expurgo da dinâmica

\footnotetext{
7 \{é\}

${ }^{8}$ Ver GLOVER, E. Freud or Jung. New York: W. W. Norton, 1950.

${ }^{9}$ \{promovem\}
} 
instintual e da redução de sua parte na vida mental. Purificada desse modo, a psique pode ser novamente redimida pela ética idealista e pela religião; e a teoria psicanalítica do aparelho mental pode ser reescrita como uma filosofia da alma. Assim fazendo, os revisionistas descartaram aquelas ferramentas psicológicas de Freud que eram ${ }^{10}$ incompatíveis com a renovação anacrônica do idealismo filosófico - as ferramentas mesmas com as quais Freud tinha descoberto as raízes instintuais e sociais da personalidade. Além disso, dá-se agora a fatores e relações secundários (entre a pessoa madura e seu ambiente cultural) a dignidade de processos primários - uma troca de orientação projetada para enfatizar a influência da realidade social na formação da personalidade. Entretanto, nós acreditamos que nessa mudança de ênfase acontece o exato oposto: o impacto da sociedade sobre a psique é enfraquecido. Enquanto Freud, focando nas vicissitudes dos instintos primários, havia descoberto ${ }^{11}$ a sociedade na camada mais escondida do gênero e do homem individual, os revisionistas, visando a forma reificada, acabada, em vez da origem das instituições e relações societárias, não conseguem compreender o que essas instituições e relações fizeram com a personalidade que elas deveriam realizar. Confrontada com as escolas revisionistas, a teoria de Freud assume agora uma nova significação: ela revela, mais do que jamais o fez antes, a profundidade de sua crítica e talvez pela primeira vez - aqueles elementos seus que transcendem a ordem prevalecente e vinculam a teoria da repressão à de sua abolição.

O fortalecimento desse elo foi o impulso inicial por trás do revisionismo da escola cultural. Os artigos iniciais de Erich Fromm são dedicados ao esforço de liberar ${ }^{12}$ a teoria de Freud de sua identificação com a sociedade dos dias atuais, de refinar as noções psicanalíticas que revelam a conexão entre estruturas econômicas

\footnotetext{
${ }^{10}\{$ são\}

${ }^{11}$ \{descobriu\}

${ }^{12}$ \{procuram liberar\}
} 
e instintuais, e ao mesmo tempo indicar a possibilidade do progresso para além da cultura \{"\}patricêntrico-aquisitiva\{"\}. Fromm enfatiza a substância sociológica da teoria de Freud: a psicanálise compreende os fenômenos sociopsicológicos como

\begin{abstract}
processos de adaptação ativa e passiva do aparelho instintual à situação socioeconômica. $\mathrm{O}$ próprio aparelho instintualé-em certos aspectos fundamentais - um dado biológico, mas é altamente modificável; as condições econômicas são os fatores formativos primários de modificação. ${ }^{13}$
\end{abstract}

Subjazendo à organização societária da existência humana, encontram-se carências e necessidades libidinais básicas: altamente plásticas e flexíveis, elas são moldadas e utilizadas para "cimentar" a sociedade em questão. ${ }^{14}$ Desse modo, naquilo que Fromm denomina a sociedade \{“\}patricêntrico-aquisitiva\{"\} \{(definida neste estudo em termos do princípio do desempenho)\}, os impulsos

${ }^{13}$ Über Methode und Aufgabe einer analytischen Sozialpsychologie. Zeitschrift für Sozialforschung, v. I, 1932, p. 39-40. [Edição brasileira: Método e função de uma psicologia social analítica. in: A crise da psicanálise. Rio de Janeiro: Zahar Editores, 1977, p. 146-7. O original alemão afirma o seguinte: “[...] Prozesse der aktiven und passiven Anpassung des Triebapparates an die sozial-ökonomische Situation. Der Triebapparat selbst ist - in gewissen Grundlagen - biologisch gegeben, aber weitgehend modifizierbar; den ökonomischen Bedingungen kommt die Rolle als primär formenden Faktoren $z u^{\prime \prime}$. A tradução brasileira acompanha a versão para o inglês publicada por Fromm em 1970, e põe o trecho em itálico. Essa marcação não consta no original de 1932, e por isso Marcuse não a acrescenta à citação correspondente. Marcuse traduz por "primary modifying factors" - fatores primários de modificação - o que a versão de Fromm (e consequentemente a edição brasileira) denominam "primary formative factors" - fatores formativos primários. Na letra de Marcuse, a ênfase recai sobre a substância biológica dos instintos como aquilo que é modificado. Fromm, relendo seu trabalho já na maturidade, opta por enfatizar as circunstâncias econômicas - e portanto o que a psicanálise consideraria como fator etiológico "acidental" - em seu papel formador do caráter.]

${ }^{14}$ \{a sociedade dada\} 
libidinais e sua satisfação (e desvio) são coordenados com os interesses da dominação, e tornam-se uma força estabilizadora que liga a maioria à minoria dominante. Ansiedade, amor, confiança até mesmo a vontade de liberdade e a solidariedade com o grupo ao qual se pertence ${ }^{15}$ vêm a servir às relações economicamente estruturadas de dominação e de subordinação. Com a obsolescência histórica de uma sociedade estabelecida, com o crescimento de seus antagonismos internos, os vínculos mentais tradicionais são afrouxados:

As forças libidinais devêm livres para novos usos, e assim mudam sua função social. Agora, elas já não contribuem mais para a preservação da sociedade, mas conduzem à construção ${ }^{16}$ de novas formações sociais; deixam de ser cimento, por assim dizer, e tornam-se dinamite. ${ }^{17}$

Fromm deu prosseguimento a essa concepção em seu artigo sobre "O significado sociopsicológico da teoria do matriarcado" ["Das sozialpsychologische Bedeutung der Mutterrechtstheorie"]. ${ }^{18}$

\footnotetext{
${ }^{15}$ Ibid., p. 51, 47. [Edição brasileira: A crise da psicanálise, pp. 157, 155.]

${ }^{16}$ \{conduzem à construção\}
}

${ }^{17}$ Ibid., p. 53. [Edição brasileira: A crise da psicanálise, p. 160. O original alemão diz: "Libidinöse Kräfte werden zu neuen Verwendungen frei und verändern damit ihre soziale Funktion. Sie tragen nun nicht mehr dazu bei, die Gesellschaft zu erhalten, sondern sie führen zum Aufbau neuer Gesellschaftsformationen, sie hören gleichsam auf, Kitt zu sein und werden Sprengstoff'. A edição brasileira acompanha a versão de Fromm em 1970, que substitui o alemão "Kräfte" pelo inglês "energies". Por isso, começa a sentença com: "As energias libidinais". Marcuse, ao contrário, sustenta a versão mais apropriada do original: "forces". Marcuse verte "führen" por "strive for" na primeira versão do texto, e por "lead to" na segunda. Fromm opta por "contribute to", e acrescenta aspas ao redor de "cement".]

${ }^{18}$ Zeitschrift für Sozialforschung, v. III, 1934. [Edição brasileira: A teoria do direito materno e sua relevância para a psicologia social. in: A crise da psicanálise. Rio de Janeiro: Zahar Editores, 1977. Marcuse traduz o título do 
As próprias intuições [insights] de Freud sobre o caráter histórico das modificações dos impulsos viciam sua equação do Princípio de Realidadecomasnormas dacultura patricêntrico-aquisitiva. Fromm enfatiza que a ideia da cultura matricêntrica - independentemente de seu mérito antropológico - visiona um Princípio de Realidade ligado não ao interesse da dominação, mas a relações libidinais gratificadas entre os homens. A estrutura instintual demanda, em vez de impedir, a ascensão de uma civilização livre sobre a base das conquistas da cultura patricêntrica, mas o faz através da transformação de suas instituições:

\begin{abstract}
A sexualidade oferece uma das possibilidades mais fortes e elementares de satisfação e felicidade. Se essas possibilidades fossem permitidas dentro dos limites postos pela necessidade de desenvolvimento produtivo da personalidade, ao invés [daqueles postos] pelo objetivo da dominação das massas, a realização dessa importante \{possibilidade de\} felicidade conduziria necessariamente a um fortalecimento da reivindicação de gratificação e de felicidade em outras esferas da existência humana. A realização dessas reivindicações exige a disponibilidade dos meios materiais necessários para sua satisfação, e deveria levar então à explosão da ordem social predominante. ${ }^{19}$
\end{abstract}

artigo para o inglês, mas não fornece o original alemão, que acrescentamos aqui.]

${ }^{19} \mathrm{Ibid} .$, p. 215. [Edição brasileira: Ibid., p. 122. A passagem é digna de atenção, pois apresenta uma ocorrência do conceito de "desenvolvimento produtivo da personalidade" já em um dos trabalhos da fase freudiana de Fromm. O original alemão diz o seguinte: "Die Sexualität bietet eine der elementarsten und stärksten Befriedigungs- und Glücksmöglichkeiten. Wäre sie in den Grenzen, wie sie aus der Notwendigkeit der produktiven Entfaltung der Persönlichkeit, nicht aber aus den Zwecken der Beherrschung der Massen bedingt sind, zugelassen, so würde die Erfüllung dieses einen wichtigen Glücksmöglichkeit notwendigerweise zu einer Verstärkung der Ansprüche auf Befriedigung und Glück in anderen Lebenssphären führen, Ansprüche, die, da ihre Sättigung materielle Mittel erforderte, zu Sprengung der bestehenden gesellschaftlichen Ordnung führen müssten". Marcuse considera 
O conteúdo social da teoria freudiana torna-se manifesto: refinar os conceitos psicanalíticos significa refinar sua função crítica, sua oposição à forma predominante de sociedade. E essa função sociológica crítica da psicanálise deriva do papel fundamental da sexualidade como "força produtiva"; as demandas libidinais propelem o progresso rumo à liberdade e a gratificação universal das necessidades humanas para além do estágio patricêntricoaquisitivo. Inversamente, o enfraquecimento da concepção psicanalítica, e especialmente da teoria da sexualidade, deve levar a um enfraquecimento da crítica sociológica e a uma redução da substância social da psicanálise. Ao contrário do que parece, isso é o que aconteceu nas "escolas culturais". Paradoxalmente (mas apenas em aparência paradoxalmente), tal desenvolvimento foi uma consequência das melhorias na terapia.

Fromm dedicou um artigo admirável à "Condicionalidade social da terapia psicanalítica" ["Die gesellschaftliche Bedingtheit der psychoanalytischen Therapie"], no qual ele mostrou ${ }^{20}$ que a

que o sujeito da segunda frase são "as possibilidades", enquanto a versão para o inglês de Fromm - e a tradução correspondente para o português consideram que é ainda "a sexualidade". Marcuse traduz por "possibility" possibilidade - o que Fromm (e a edição brasileira) traduzem por "opportunity" - oportunidade. Em Marcuse, consta como "spheres of human existence" - esferas da existência humana - o que em Fromm são "areas of life" - áreas da vida. Marcuse traduz como "limits set by the need for the productive development of the personality" - limites postos pela necessidade de desenvolvimento produtivo da personalidade - o que em Fromm é "the full extent required for the productive development of the human personality" - toda a extensão requerida para o desenvolvimento produtivo da personalidade humana. Marcuse interpreta, pois, a "necessidade" ("Notwendigkeit") do desenvolvimento pessoal em termos de uma restrição imposta à personalidade; lê "den Grenzen" - o limite -, por assim dizer, "de fora para dentro" - o que está em consonância com sua ideia de que o "caráter produtivo" é um conceito conformista. Fromm, ao contrário, vê naquela "necessidade" justamente aquilo que está na contramão das restrições impostas socialmente à pessoa, e portanto lê "den Grenzen", digamos, "de dentro para fora" - assumindo o ponto de vista da personalidade.]

${ }^{20}$ \{mostra\} 
situação psicanalítica (entre analista e paciente) é uma expressão específica da "tolerância burguesa-liberal", e como tal depende da existência de tal tolerância na sociedade. Mas por trás da atitude tolerante do analista "neutro", esconde-se o "respeito pelos tabus sociais da burguesia". ${ }^{21}$ Fromm traça a eficácia desses tabus até o núcleo mesmo da teoria freudiana, na posição de Freud em relação à moralidade sexual. Fromm contrasta essa atitude a outra concepção de terapia, formulada talvez pela primeira vez por Ferenczi, de acordo com a qual o analista rejeita tabus patricêntrico-autoritários e entra em uma relação positiva, em vez de neutra, com o paciente. A nova concepção é caracterizada principalmente por uma "realização da demanda humana por felicidade" e a "liberação da moralidade de seu caráter tabu". ${ }^{22}$ Entretanto, com essas demandas, a psicanálise enfrenta um dilema fatal. A "demanda por felicidade", se verdadeiramente afirmada, agrava o conflito com uma sociedade que permite apenas felicidade controlada, e a exposição dos tabus morais estende esse conflito a um ataque às camadas protetoras vitais da sociedade. Isso pode ser ainda praticável em um ambiente social no qual a tolerância é um elemento constitutivo de relações pessoais, econômicas e políticas, mas deve comprometer a própria ideia de "cura", e até a própria existência da psicanálise, quando a sociedade já não pode se permitir essa tolerância. A atitude afirmativa para com a demanda

${ }^{21}$ Zeitschrift für Sozialforschung, v. IV, 1935, p. 374-5. [Não há versão brasileira. Em alemão, constam: "bürgerlich-liberalistischen Toleranz", "neutral" e "Respekt vor den gesellschaftlichen Tabus des Bürgertums". Tanto Marcuse (aqui) quanto Fromm (mais adiante) dão uma tradução menos literal do título para o inglês: optam por "The social conditions of psychoanalytic therapy" (As condições sociais da terapia psicanalítica). $\mathrm{O}$ acréscimo do título em alemão no corpo do texto é nosso.]

${ }^{22}$ Ibid., p. 395. [O alemão diz: "die Verwirklichung der menschlichen Ansprüche auf Glück" e "die Befreiung der Moral von ihrem tabuistischen Charakter". Marcuse desdobra "Verwirklichung" (efetivação) em uma hipérbole - "unconditional affirmation" (afirmação incondicional) -; substitui "menschlichen" (humano) por "the patient's" (do paciente), e traduz a última parte da segunda expressão (caráter de tabu) por "tabooistic features" (características de tabu), no plural.] 
de felicidade torna-se então praticável apenas se a felicidade e o desenvolvimento "produtivo" da personalidade\{"\} são redefinidos de modo a tornarem-se compatíveis com os valores prevalecentes - quer dizer, se eles são internalizados e idealizados. E essa redefinição deve, por sua vez, implicar um enfraquecimento do conteúdo explosivo da teoria psicanalítica, bem como de sua crítica social explosiva. Se esse é de fato (tal como pensa o autor ${ }^{23}$ o curso que o revisionismo tomou, então isso se deve à dinâmica social objetiva do período: em uma sociedade antiliberal, ${ }^{24}$ a felicidade individual e o desenvolvimento produtivo estão em contradição com a sociedade; se [a felicidade individual e o desenvolvimento produtivo] são definidos como valores a serem realizados dentro desta sociedade, tornam-se eles mesmos repressivos.

\section{II}

A discussão subsequente preocupa-se apenas com os estágios mais recentes da psicologia neofreudiana\{\} em que as características regressivas do movimento aparecem como predominantes. A discussão não tem nenhum outro propósito, senão o de dar relevo, por contraste, às implicações críticas da teoria psicanalítica, enfatizadas nos capítulos anteriores deste estudo; ${ }^{25}$ os méritos terapêuticos das escolas revisionistas estão completamente fora do escopo desta discussão.

Essa limitação impõe-se não apenas por minha própria falta de competência, mas também por conta de uma discrepância entre teoria e terapia inerente à própria psicanálise. Freud estava plenamente ciente [was fully aware] dessa discrepância, que pode ser formulada - demasiado simplificadamente - da seguinte forma: enquanto a teoria psicanalítica reconhece que a doença do indivíduo é causada e sustentada em última instância pela doença

\footnotetext{
${ }^{23}\{$ (tal como eu penso)\}

${ }^{24}$ \{repressiva\}

${ }^{25}$ \{as implicações críticas ... enfatizadas neste estudo\}
} 
de sua civilização, a terapia psicanalítica objetiva curar o indivíduo de modo que ele possa continuar a funcionar como parte dessa civilização ${ }^{26}$ sem render-se totalmente a ela. A aceitação do Princípio de Realidade, com o qual a terapia psicanalítica termina, significa para o indivíduo a aceitação da regimentação civilizada de suas necessidades instintuais, especialmente da sexualidade.

Na teoria de Freud, a civilização aparece como estabelecida em contradição com os instintos primários e com o Princípio do Prazer. Mas este último sobrevive no Id, e o Eu civilizado deve lutar permanentemente contra seu passado atemporal e contra seu futuro proibido. Teoricamente, a diferença entre saúde mental e neurose reside apenas no grau e na efetividade da resignação: saúde mental é resignação bem-sucedida, eficiente - normalmente tão eficiente que ela se apresenta como satisfação moderadamente feliz. A normalidade é uma condição precária: “Tanto a neurose como a psicose são expressão da rebeldia do Id contra o mundo externo, de sua 'dor', de sua falta de vontade de adaptar-se à necessidade-à Ananké, ou, caso se prefira, de sua incapacidade fazêlo, ${ }^{\prime 27}$ Essa rebelião, embora origine-se na "natureza" instintual do homem, é uma doença que tem de ser curada - não apenas porque ela \{está lutando\} contra um poder irremediavelmente superior, mas [também] porque ela \{está lutando\} contra a "necessidade". Deve haver repressão $\{e\}$ infelicidade, caso a civilização deva prevalecer. A "meta" do Princípio do Prazer - a saber, "ser feliz"

\footnotetext{
${ }^{26}$ \{de uma civilização doente\}

${ }^{27}$ The loss of reality in neurosis and psychosis. in: Collected papers, vol. II. London: Hogarth Press, 1950, p. 279. [Edição brasileira: A perda da realidade na neurose e na psicose. in: Obras completas, volume 16. São Paulo: Companhia das Letras, 2011, p. 217. Edição alemã: Der Realitätsverlust bei Neurose und Psychose. in: Gesammelte Werke, Band XIII. London: Imago Publishing, 1940, p. 365. A edição de Marcuse verte por "'pain', unwillingness", - "dor", falta de vontade - o que na versão brasileira é "desprazer". O original alemão advoga inequivocamente a favor da versão brasileira: o substantivo é "Unlust", sem qualquer acréscimo ulterior.]
} 
- "é inatingível", ${ }^{28}$ embora os esforços para atingi-lo não devam e não possam ser abandonados. Em última análise, ${ }^{29}$ a questão é apenas quanta resignação o indivíduo consegue suportar sem entrar em colapso. Nesse sentido, a terapia é um curso de resignação: muito se ganhará se conseguirmos "transformar sua miséria histérica na infelicidade cotidiana" ${ }^{30}$ que é o quinhão habitual da humanidade. Essa meta certamente não implica (ou não deveria implicar) que o paciente torna-se capaz de adaptar-se completamente a um ambiente repressivo de suas habilidades e aspirações maduras; ainda assim, o analista, como médico, deve aceitar o enquadramento social dos fatos no qual o paciente tem de viver e que ele não pode alterar. ${ }^{31} \quad$ Esse núcleo irredutível de conformidade é ainda mais fortalecido pela convicção de Freud de que a base repressiva da civilização não pode ser alterada de modo algum - nem mesmo na escala supraindividual, societária. Consequentemente, as intuições [insights] críticas da psicanálise ganham sua força plena apenas no campo da teoria - e talvez

${ }^{28}$ Civilization and its discontents. London: Hogarth Press, 1949, p. 39. [Edição brasileira: $\mathbf{O}$ mal-estar na civilização. in: Obras completas, volume 18. São Paulo: Companhia das Letras, 2010, p. 40. Edição alemã: Das Unbehagen in der Kultur, in: Gesammelte Werke, Band XIV. Londres: Imago Publishing, 1955, p. 442. A edição de Marcuse verte por "goal" - meta - o que aparece na versão brasileira como "programa". O original diz "Programm", aproximandose da versão brasileira.]

${ }^{29}$ \{No longo prazo\}

${ }^{30}$ BREUER, J; FREUD, S. Studies in hysteria. New York: Nervous and Mental Disease Monograph no. 61, 1936, p. 232. Veja-se A general introduction to psyschoanalysis. New York: Garden City Publishing Co., 1943, p. 397s. [Edições brasileiras: Estudos sobre histeria. São Paulo: Companhia das Letras, 2016, p. 427. Conferências introdutórias à psicanálise. in: Obras completas, volume 13. São Paulo: Companhia das Letras, 2014, p. 604-5. O original alemão da passagem encontra-se em BREUER e FREUD, Studien über Hysterie. in: Gesammelte Werke, Band I. London: Imago Publishing, 1952, p. 312.]

${ }^{31}$ Ver New introductory lectures. New York: W. W. Norton, 1933, p. 206. [Edição brasileira: Novas conferências introdutórias à psicanálise. in: Obras completas, volume 18. São Paulo: Companhia das Letras, 2010, p. 313.] 
particularmente onde a teoria está o mais radicalmente apartada da terapia: na "metapsicologia" de Freud. As escolas revisionistas obliteraram essa discrepância entre teoria e terapia ao assimilar aquela a esta. Essa assimilação deu-se de duas maneiras. Primeiro, os conceitos mais especulativos e "metafísicos", que não estavam sujeitos a nenhuma verificação clínica (como o Instinto de Morte, a hipótese da Horda Primeva, o assassinato do pai primordial e suas consequências), foram minimizados ou descartados por completo. Além disso, nesse processo alguns dos conceitos mais decisivos de Freud (a relação entre Id e Eu; a função do inconsciente; o escopo e significância da sexualidade) foram redefinidos de tal maneira que suas conotações explosivas foram quase completamente eliminadas. A dimensão profunda do conflito entre o indivíduo e sua sociedade, entre a estrutura instintual e o reino da consciência, foi achatada. A psicanálise foi reorientada à psicologia da consciência tradicional, de textura pré-freudiana. Não se questiona aqui o direito a tais reorientações tendo em vista a terapia e a prática bem-sucedidas; mas os revisionistas converteram a eliminação ${ }^{32}$ da teoria freudiana em uma nova teoria, e apenas o significado dessa nova teoria será doravante discutido. A discussão negligenciará a diferença entre os vários grupos revisionistas e vai se concentrar na atitude teórica comum a todos eles. Ela é extraída a partir de trabalhos representativos de Erich Fromm, Karen Horney e Harry Stack Sullivan. Clara Thompson ${ }^{33}$ é tomada com uma historiadora representativa dos revisionistas.

As objeções principais dos revisionistas a Freud podem ser resumidas da seguinte forma: Freud subestimou gravemente a medida em que o indivíduo e suas neuroses são determinados por conflitos com seu ambiente. A "orientação biológica" de Freud o levou a concentrar-se no passado filogenético e ontogenético do indivíduo: ele considerou o caráter como essencialmente fixado

\footnotetext{
32 o enfraquecimento\}

${ }^{33}$ THOMPSON, C. Psychoanalysis: evolution and development. New York: Hermitage House, Inc., 1951. [Edição brasileira: Evolução da psicanálise. Rio de Janeiro: Zahar Editores, 1969.]
} 
a partir do quinto ou sexto ano [de vida] (se não antes disso), e interpretou o destino do indivíduo em termos de instintos primários e de suas vicissitudes, especialmente a sexualidade. Em contraposição, os revisionistas deslocam a ênfase "do passado ao presente" 34 , do nível biológico ao cultural, da "constituição" do indivíduo ao seu ambiente. ${ }^{35}$ "Pode-se compreender melhor o desenvolvimento biológico se se descarta completamente o conceito de libido", e se interpretam os diferentes estágios "em termos de crescimento e de relações humanas". ${ }^{36} \mathrm{O}$ assunto da psicanálise torna-se então a "personalidade total" em sua "relacionalidade ao mundo" 37 e os "aspectos construtivos do indivíduo", suas "potencialidades produtivas e positivas", recebem a atenção que merecem. Freud \{era frio, duro, destrutivo e pessimista. Ele\} não viu que doença, tratamento e cura eram uma questão de "relações interpessoais" nas quais personalidades totais estão engajadas de ambos os lados. A concepção de Freud $\mathrm{e}^{38}$ predominantemente relativista: ele assumiu que a psicologia pode "ajudar-nos a compreender a motivação de juízos de valor, mas não a estabelecer a validade desses mesmos juízos" ${ }^{39}$ Consequentemente, sua psicologia não contém ética alguma, ou apenas sua ética pessoal. Além disso, Freud tinha um conceito

34 THOMPSON, loc. cit., p. 15, 182. [Edição brasileira: loc. cit., p. 21, 165.]

${ }^{35}$ Ibid., p. 9, [13, 26 f, 155]. [Edição brasileira: Ibid., p. 16, 19, 30-1, 141. Marcuse fornece apenas a primeira página.]

${ }^{36}$ Ibid., p. 42. [Edição brasileira: Ibid., p. 45.]

${ }^{37}$ [No vocabulário de Fromm, a diferença entre "relatedness" e "relation" ou "relationship" é significativa. "Relatedness" denota, não uma relação discreta, finita, mas o próprio fato ou condição de estar relacionado a algo. Daí a opção pelo termo pouco comum em português, "relacionalidade". Veja-se The sane society.]

38 fera\}

${ }^{39}$ FROMM, E. Man for himself. New York: Rinehart and Co., 1947, p. 34. [Edição brasileira: Análise do homem. Rio de Janeiro: Zahar Editores, p. 39. No original de Fromm, "motivation" e "validity" (motivação e validade) estão em itálico, mas Marcuse não acrescenta essa modificação gráfica.] 
"estático" de sociedade ${ }^{40}$, e pensava que a sociedade desenvolveuse como "um mecanismo para controlar os instintos do homem", enquanto os revisionistas sabem "a partir do estudo comparativo das culturas" que "o homem não é biologicamente dotado de impulsos animais perigosos fixos, e que a função da sociedade não é apenas a de controlar esses impulsos". Eles insistem que a sociedade "não é um conjunto estático de leis instituídas no passado, ao tempo do assassinato do pai primordial, mas, antes, uma rede crescente, mutável, em desenvolvimento, de experiências e de comportamento interpessoais". A isso acrescentam-se as seguintes intuições [insights]:

Não é possível tornar-se um ser humano, exceto através da experiência cultural. A sociedade cria novas necessidades nas pessoas. Algumas das novas necessidades levam a uma direção construtiva e estimulam o desenvolvimento subsequente. São dessa natureza as ideias de justiça, igualdade e cooperação. Algumas das novas necessidades levam a uma direção destrutiva e não são boas para o homem. Competitividade indiscriminada e exploração impiedosa dos desamparados são exemplos de produtos destrutivos da cultura. Quando os elementos destrutivos predominam, temos uma situação que fomenta a guerra. ${ }^{41}$

Essa passagem pode servir como um ponto de partida para exemplificar $^{42}$ o declínio da teoria nas escolas revisionistas. Há, em primeiro lugar, a elaboração do óbvio, da sabedoria rotineira. ${ }^{43}$ Em seguida, há a adução de conceitos sociológicos. Em Freud, eles são incluídos e desenvolvidos nos próprios conceitos básicos;

\footnotetext{
40 vvia a sociedade como estática\}

41 THOMPSON, loc. cit., p. 136, 142-3. [Edição brasileira: THOMPSON, loc. cit., p. 125, 131.]

42 \{para mostrar\}

${ }^{43}$ \{cotidiana\}
} 
aqui, aparecem como fatores externos, incompreendidos. Há, além disso, a distinção entre bom e mau, construtivo e destrutivo (\{de acordo com\} Fromm: produtivo e improdutivo, ${ }^{44}$ positivo e negativo), que não é derivada de nenhum princípio teórico, mas simplesmente tomada da ideologia prevalecente. Por essa razão, a distinção é meramente eclética, exterior à teoria, e equivalente ao $\{$ slogan $\}$ conformista "acentue o positivo": Freud estava certo, a vida é má, repressiva, destrutiva - mas não é tão má, repressiva, destrutiva; há também os aspectos construtivos, positivos. A sociedade não é apenas isso, mas também aquilo; o homem não é apenas contra si mesmo, mas também a favor de si mesmo. ${ }^{45}$ Essas distinções são insignificantes e - como tentaremos mostrar - até mesmo equivocadas, a não ser que seja realizada a tarefa (que Freud tomou para si): demonstrar como, sob o impacto da civilização, os dois "aspectos" são interrelacionados na própria dinâmica instintual, e como um converte-se inevitavelmente no outro em virtude dessa dinâmica. Aquém dessa demonstração, o aperfeiçoamento revisionista da "unilateralidade" de Freud é um descarte não qualificado de sua concepção teórica fundamental. Entretanto, o termo "ecletismo"46 não expressa adequadamente a substância da filosofia revisionista. Suas consequências para a teoria psicanalítica são muito mais graves: a "suplementação" revisionista da teoria freudiana, especialmente sua adução de

${ }^{44}$ [Marcuse contrapõe "productive" e "unproductive" (improdutivo), de conotação econômica mais forte. Fromm costuma optar por "non-productive", "não produtivo", pois o seu conceito de produtividade não se refere imediatamente à atividade material, aos produtos do trabalho, mas à capacidade do caráter de produzir e reproduzir a si mesmo, em sua estrutura interna - o que, não obstante, tem na atividade material um suporte necessário, embora não exaustivo. Cf. Man for himself.]

${ }^{45}$ [O trecho alude ao título de dois livros: Man against himself, publicado por Karl Menninger em 1938, e Man for himself, publicado por Erich Fromm em 1947. Mais abaixo, discutiremos a peculiaridade do título de Fromm e as dificuldades envolvidas em sua tradução.]

${ }^{46}\{$ ecletismo $\}$ 
fatores culturais e ambientais, consagra uma imagem falsa da civilização, particularmente da sociedade de hoje em dia. Ao minimizar a medida e a profundidade do conflito, os revisionistas proclamam uma solução falsa, porém fácil. Nós devemos oferecer aqui apenas uma breve ilustração:

Uma das demandas mais prezadas dos revisionistas é que a "personalidade total" do indivíduo - em vez de sua primeira infância, sua estrutura biológica ou sua condição psicossomática seja tornada o assunto da psicanálise:

A diversidade infinita das personalidades é, em si mesma, característica da existência humana. Por personalidade, eu compreendo a totalidade das qualidades psíquicas herdadas e adquiridas que são características de um indivíduo e o tornam único. ${ }^{47}$

Penso estar claro que a concepção freudiana da contratransferência deve distinguir-se da concepção atual da análise como processo interpessoal. $\mathrm{Na}$ situação interpessoal, encara-se o analista como relacionado ao paciente, não só através de seus afetos deformados, mas também através de sua personalidade saudável. Isto é, a situação analítica é, essencialmente, uma relação humana. ${ }^{48}$

O pressuposto ao qual estou conduzindo é este: a personalidade tende ao estado que nós chamamos saúde mental ou sucesso adaptativo interpessoal, não obstante as limitações da aculturação. A direção básica do organismo é adiante. ${ }^{49}$

${ }^{47}$ FROMM, loc. cit., p. 50. [Edição brasileira: FROMM, loc. cit., p. 52. Marcuse não indica a existência de uma mudança de parágrafo entre a primeira sentença e as próximas.]

${ }^{48}$ THOMPSON, loc. cit., 108. [Edição brasileira: THOMPSON, loc. cit., p. 102.]

${ }^{49}$ SULLIVAN, H. Conceptions of modern psychiatry. Washington: William Alanson White Psychiatric Foundation, 1947, p. 48. [Não há edição brasileira. A tradução literal do primeiro termo da sentença, "preconception", seria "preconcepção". Fora de contexto, entretanto, o termo soa equívoco. A 
\{Mais uma vez, o óbvio ("diversidade de personalidades", análise como um "processo interpessoal"), por não ser compreendido, mas simplesmente afirmado e utilizado, torna-se uma meia-verdade falsa, já que a metade faltante altera o conteúdo do fato óbvio.\}

As passagens \{citadas\} acima testemunham a confusão entre ideologia e realidade que prevalece entre as escolas revisionistas. É verdade que o homem aparece como um indivíduo que "integra" uma diversidade de qualidades herdadas e adquiridas em uma personalidade total, e que esta última desenvolve-se em sua relação ao mundo (coisas e pessoas) sob condições diversas e variadas. Mas essa personalidade e seu desenvolvimento são pré-formados ao nível da estrutura instintual mais profunda, e essa preformação, a obra da civilização acumulada, faz das diversidades e da autonomia do "crescimento" individual fenômenos secundários. ${ }^{50} \mathrm{O}$ quanto de realidade está por trás da individualidade depende do escopo, da forma e da eficácia dos controles repressivos prevalecentes no respectivo estágio da civilização. ${ }^{51}$ A personalidade autônoma, no sentido da "singularidade" ["uniqueness"] criativa e da completude de sua existência, tem sido sempre um privilégio de pouquíssimos.

No estágio atual, a personalidade tende a um padrão de reações estandardizado, estabelecido pela hierarquia de poder e de funções e por seu aparato técnico, intelectual e cultural. O analista e seu paciente partilham dessa alienação, e como ela geralmente não se manifesta em nenhum sintoma neurótico, mas, ao contrário, como a marca distintiva da "saúde mental", não aparece na consciência revisionista. Quando o processo de alienação é discutido, ele é

passagem que Marcuse cita consta de uma enumeração do que seriam, para Sullivan, "the preconceptions that underlie the psychiatric interview" (p. 46) - daí a opção pelo termo mais convencional entre nós, "pressupostos", no sentido de condicionantes dados, antepostos à entrevista psiquiátrica.]

${ }^{50}$ \{significa que as diversidades e a autonomia do "crescimento individual" são fenômenos secundários.\}

${ }^{51}$ \{no estágio dado da civilização\} 
geralmente tratado, não como o todo que é, mas como um aspecto negativo do todo. Certamente, a personalidade não desapareceu (essa seria uma formulação fatalmente equivocada): ela continua a florescer, é até mesmo fomentada e educada, mas de tal modo que as expressões da personalidade encaixem-se e sustentem perfeitamente o padrão socialmente desejado de comportamento e pensamento. Elas tendem, portanto, a cancelar a individualidade. Esse processo, que foi completado na "cultura de massas" da civilização industrial tardia, vicia o conceito das relações interpessoais, caso ele queira denotar mais do que o fato inegável de que todas as relações nas quais o ser humano se encontra são, ou relações com outras pessoas, ou abstrações delas. Se, para além desse truísmo, o conceito implica mais - a saber, que "duas ou mais pessoas vêm a definir uma situação integrada" que é feita de "indivíduos" 52 -, então a implicação é falaciosa. Pois as situações individuais são os derivados e aparências do destino geral, e como mostrou Freud, é este último que contém a pista para o destino do indivíduo. A repressividade geral molda o indivíduo e universaliza até mesmo suas características mais pessoais. Em consonância com isso, a teoria de Freud está consistentemente orientada à primeira infância - o período formativo do destino universal no indivíduo. As relações maduras subsequentes "recriam" as relações formativas. As relações decisivas são, portanto, aquelas que são menos interpessoais. Em um mundo alienado, espécimes do gênero confrontam-se uns aos outros: pai $\{\mathrm{e}\}$ filho, macho $\{\mathrm{e}\}$ fêmea; depois mestre $\{\mathrm{e}\}$ servo, chefe $\{\mathrm{e}\}$ empregado; eles estão interrelacionados inicialmente em modos específicos da alienação universal. Se, e quando, eles deixam de ser assim e evoluem para [grow into] relações verdadeiramente pessoais, ainda retêm a repressividade universal que eles superam como seu negativo abrangido \{e dominado\} - e então já não requerem tratamento.

52 BEAGLEHOLE, E. Interpersonal theory and social psychology. in: Patrick Mullahy (ed.), A study in interpersonal relations. New York: Hermitage Press, 1950, p. 54. [Não há edição brasileira.] 


\section{III}

A psicanálise elucida o universal na experiência individual. Nessa medida, e apenas nessa medida, a psicanálise pode romper a reificação na qual as relações humanas estão petrificadas. Os revisionistas não conseguem reconhecer, ou não conseguem extrair as consequências do estado atual de alienação, que transforma a pessoa em uma função permutável e a personalidade em uma ideologia. Em contraste, os conceitos básicos "biologistas" de Freud alcançam além da ideologia e de seus reflexos: sua recusa de tratar uma sociedade reificada como uma "rede progressiva de experiências e comportamento interpessoais" e um indivíduo alienado como uma "personalidade total" corresponde à realidade \{e que contém seu verdadeiro conceito [notion] \}. Se ele se abstém de considerar a existência inumana como um aspecto negativo passageiro da humanidade em progresso, ${ }^{53}$ é mais humano que a tolerância bem-intencionada de seus críticos, ${ }^{54}$ que estigmatizam sua frieza "desumana". Freud não acredita prontamente que a "direção básica do organismo é adiante". Mesmo sem a hipótese do Instinto de Morte e da natureza conservadora dos instintos, a proposição de Sullivan é superficial e questionável. A direção "básica" do organismo aparece [como uma direção] bastante diferente nos impulsos persistentes ao alívio de tensão, à realização, ao repouso, à passividade $\{$ - a luta contra o avanço do tempo não é intrínseca apenas ao Eros Narcísico.\} As tendências sadomasoquistas dificilmente podem ser associadas com uma direção adiante na saúde mental, a não ser que "adiante" e "saúde mental" sejam redefinidos para significar quase o oposto do que são em nossa ordem social - "uma ordem social que é, em alguns sentidos, grosseiramente inadequada para o desenvolvimento de seres humanos saudáveis e felizes". ${ }^{55}$ Sullivan abstém-se

\footnotetext{
53 \{humanidade que move-se adiante\}

54 \{ele é mais humano do que seus críticos bem-intencionados e tolerantes\}

${ }^{55}$ MULLAHY, P. Introduction. A study of interpersonal relations, loc. cit., p.
} 
de tal redefinição - ele faz seus conceitos conformarem-se à conformidade:

A pessoa que acredita ter-se desfeito voluntariamente de suas amarras anteriores e aceito novos dogmas, sob os quais ela doutrinou-se diligentemente, por escolha [própria], é certamente uma pessoa que sofreu grande insegurança. Ela é muitas vezes uma pessoa cuja auto-organização [self-organization] é depreciativa e odiosa. O novo movimento deu a ela suporte grupal para a expressão de hostilidades pessoais antigas, que agora estão dirigidas contra o grupo do qual ela veio. A nova ideologia racionaliza a atividade destrutiva de tal maneira que ela parece quase - senão bastante - construtiva. A nova ideologia é especialmente paliativa do conflito [psíquico] em sua promessa de um mundo melhor que deverá erguer-se dos detritos aos quais a ordem presente deve ser antes reduzida. Nessa Utopia, ela [a pessoa] e seus companheiros serão bons e gentis - para eles não haverá mais injustiça, e assim por diante. Se o seu grupo é um daqueles mais radicais, a atividade da memória mais remota na síntese de decisões e da escolha pode ser suprimida quase completamente, e a atividade do devaneio prospectivo [pode ser] canalizada rigidamente no padrão dogmático. Neste caso, exceto por suas relações com seus companheiros radicais, o homem pode agir como se ele tivesse adquirido o tipo de personalidade psicopático discutido na terceira conferência. Ele não demonstra apreensão durável de sua própria realidade e da dos outros, e suas ações são controladas pelo oportunismo mais imediato, sem consideração do futuro provável. ${ }^{56}$

XVII. [Não há edição brasileira.]

${ }^{56}$ SULLIVAN, H. Conceptions of modern psychiatry, loc. cit., p. 96. Veja-se a resenha de Helen Merrell Lynd em The Nation, 15 de janeiro de 1949. [Não há edição brasileira.] 
\{A passagem ilumina a medida em que a teoria interpessoal é talhada com os valores do status quo. Se uma pessoa "desfez suas amarras anteriores" e "aceitou novos dogmas", presume-se que ela "sofreu grande insegurança", que sua "auto-organização é depreciativa e odiosa", que seu novo credo "racionaliza a atividade destrutiva" - em suma, que ela é [d]o tipo psicopático.\} Não ocorre a ideia ${ }^{57}$ de que a insegurança seria racional e razoável; de que não a auto-organização da pessoa, mas a dos outros é que seria depreciativa e odiosa; de que a destrutividade envolvida no novo dogma poderia ser de fato construtiva, na medida em que se dirigisse a um estágio superior de realização. Essa psicologia não tem quaisquer medidas objetivas de valor além das predominantes [hoje]: saúde, maturidade, conquista são tomadas tal como são definidas pela sociedade dada - a despeito da ciência [awareness] de Sullivan de que em nossa cultura a maturidade é "muitas vezes uma reflexão acerca de nada além do status socioeconômico de uma pessoa e outras coisas aparentadas". ${ }^{58}$

Conformidade profunda domina essa psicologia, que suspeita que todos aqueles que "desfazem-se de suas amarras anteriores" e tornam-se "radicais" sejam neuróticos (a descrição citada acima cabe bem a todos eles, de Jesus a Lenin, de Sócrates a Giordano Bruno), e que identifica quase automaticamente a "promessa de um mundo melhor" com a "Utopia", sua substância com "devaneio", e o sonho sagrado da humanidade de justiça para todos com o ressentimento pessoal de tipos desajustados (nenhuma injustiça a mais "para eles"). Essa identificação "operacional" da saúde mental com o "sucesso adaptativo" e com o progresso elimina todas as reservas com as quais Freud cercou o objetivo terapêutico de adaptação a uma sociedade desumana, e compromete então a psicanálise com essa sociedade muito mais do que Freud jamais fez.

57 \{Não se sugere que\}

58 The interpersonal theory of psychiatry. New York: W. W. Norton and Co., 1953, p. 298. [Não há edição brasileira.] 
Por trás de todas as diferenças entre formas históricas de sociedade, Freud viu a desumanidade básica comum a todas elas, e os controles repressivos que perpetuam, na própria estrutura instintual, a dominação do homem pelo homem. Por conta dessa intuição [insight], o "conceito estático de sociedade" de Freud está mais próximo da verdade do que os conceitos sociológicos dinâmicos fornecidos pelos revisionistas. A noção de que "o malestar na civilização" ${ }^{59}$ tinha suas raízes na constituição biológica do homem influenciou profundamente o conceito de Freud da função e da meta da terapia. A personalidade que o indivíduo deverá desenvolver, as potencialidades que ele deverá realizar, a felicidade que ele deverá alcançar - elas são arregimentadas desde o princípio, e seu conteúdo pode ser definido apenas em termos desse regramento. Freud destrói as ilusões tradicionais da ética idealista: a "personalidade" não é senão um indivíduo "quebrado" que internalizou a repressão e a agressão e as utilizou com êxito. Considerando o que a civilização fez do homem, a diferença no desenvolvimento de personalidades é principalmente aquela entre uma participação desproporcional ou proporcional naquela "infelicidade cotidiana" que é o quinhão comum da humanidade. Esse último é tudo que a terapia pode alcançar.

Em oposição a [Over and against] tal "programa mínimo", Erich Fromm e os outros revisionistas proclamam uma meta mais elevada da terapia: "o desenvolvimento ótimo das potencialidades da pessoa e a realização de sua individualidade". Ora, é precisamente essa meta que é essencialmente inatingível - não por causa das limitações nas técnicas psicanalíticas, mas porque a própria civilização estabelecida, em sua estrutura mesma, a nega. Pode-se definir "personalidade" e "individualidade" em termos

\footnotetext{
${ }^{59}$ [Em inglês: "civilization and its discontent". A sentença parafraseia a tradução para o inglês do título de Freud, Das Unbehagen in der Kultur, publicado em fascículos entre 1929 e 1930, e em 1930 como um livro completo. Em português, verte-se o título por $\mathbf{O}$ mal-estar na civilização, ou $\mathbf{O}$ mal-estar na cultura. Optamos pela denominação mais próxima da formulação do próprio Marcuse.]
} 
de suas possibilidades dentro da forma estabelecida de civilização, e então sua realização será, para a vasta maioria, equivalente à adaptação bem-sucedida. Ou então se as define em termos de seu conteúdo transcendente, incluindo as suas potencialidades negadas socialmente para além (e abaixo) de sua existência atual: neste caso, a sua realização implicaria a transgressão para além da forma estabelecida de civilização e rumo a modos radicalmente novos de "personalidade" e "individualidade", incompatíveis com aqueles prevalecentes. Hoje, isso significaria "curar" o paciente para tornar-se um rebelde ou (o que significa a mesma coisa) um mártir. O conceito revisionista vacila entre as duas definições. Fromm reaviva todos os valores da ética idealista que o tempo sancionou, como se ninguém jamais tivesse demonstrado suas características repressivas e conformistas. Ele fala da realização produtiva da personalidade, do cuidado, da responsabilidade e do respeito pelos semelhantes, do amor produtivo e da felicidade, como se o homem pudesse de fato praticar tudo isso e ainda permanecer são e cheio de "bem-estar" em uma sociedade que o próprio Fromm descreve como de alienação total, dominada pelas relações mercadológicas [commodity relations of the 'market']. Em uma tal sociedade, a autorrealização da "personalidade" pode avançar apenas sobre a base de uma dupla repressão: primeiro, a "purificação" do Principio do Prazer e a internalização da felicidade e da liberdade; segundo, a sua restrição razoável até que elas se tornem compatíveis com a não-liberdade e a infelicidade predominantes. Como consequência disso, produtividade, ${ }^{60}$ amor, responsabilidade, tornam-se "valores" apenas à medida que contêm resignação administrável e são praticadas dentro do quadro de atividades socialmente úteis - em outras palavras, após

${ }^{60}$ [A opção de Fromm por "productiveness", em vez de "productivity", segue as mesmas razões de sua opção por "relatedness", em vez de "relation" ou "relationship" - e, mais tarde, em The revolution of hope, por "activeness", em vez de "activity". Procura denotar um modo contínuo de relação a si mesmo e ao mundo, no qual o caráter põe a si próprio e aos seus elementos, desenvolvendo em ato as suas potencialidades - autoproduzindo-se, enfim.] 
sublimação repressiva; e então elas envolvem a negação efetiva da produtividade e da responsabilidade livres - a renúncia à felicidade. Por exemplo, a produtividade, proclamada como uma meta do indivíduo saudável \{sob o princípio do desempenho\}, deve normalmente (isto é, fora das exceções criativas, "neuróticas" e "excêntricas") mostrar-se no bom negócio, na boa administração, no bom serviço, com expectativa razoável de sucesso reconhecido. $\mathrm{O}$ amor deve ser libido semissublimada e até inibida, mantendo-se alinhado com as condições sancionadas impostas à sexualidade. Esse é o significado aceito, "realista", de produtividade e amor. Mas os mesmos termos também denotam a realização livre do homem, ou a ideia dessa realização. $\mathrm{O}$ uso revisionista desses termos joga com essa ambiguidade que designa as faculdades do homem - tanto as livres quanto as não-livres, tanto as mutiladas quando as integradas -, investindo desse modo o Princípio de Realidade estabelecido com a grandeza de promessas que só podem ser redimidas além desse Princípio de Realidade.

Essa ambiguidade faz a filosofia revisionista aparecer como crítica onde é conformista, como política onde é moralista. Muitas vezes, o estilo trai por si mesmo a atitude. Seria revelador fazer uma análise comparativa dos estilos freudiano e neofreudiano. Este último, nos escritos mais filosóficos, frequentemente aproxima-se do estilo do sermão, ou do estilo do assistente social; ele é elevado, porém claro; permeado de boas intenções e tolerância, e entretanto movido por um "esprit de sérieux" [espírito de seriedade] que transforma valores transcendentais em fatos da vida cotidiana. $\mathrm{O}$ que tornou-se uma farsa é tomado como real. Em contraste a isso, há uma forte conotação [undertone] de ironia no uso que Freud faz [de termos como] "liberdade", "felicidade", "personalidade": esses termos parecem carregar aspas invisíveis, ou seu conteúdo negativo é explicitamente afirmado. Freud abstém-se de chamar a repressão por qualquer outro nome que não o seu próprio; os neofreudianos às vezes a sublimam em seu oposto.

Mas a combinação da psicanálise revisionista com a ética idealista não é simplesmente uma glorificação da adaptação. A 
orientação "sociológica" ou "cultural" ${ }^{11}$ neofreudiana fornece o outro lado da figura - o "não apenas, mas também". A terapia de adaptação é fortemente rejeitada; ${ }^{62}$ a "deificação" do sucesso é denunciada.$^{63} \mathrm{~A}$ sociedade e a cultura dos dias de hoje são acusadas de oferecer grande impedimento à realização da pessoa saudável e madura; o princípio da "competitividade, e a hostilidade potencial que o acompanha, permeiam todas as relações humanas". ${ }^{64}$ Os revisionistas alegam que a sua psicanálise é em si mesma uma crítica da sociedade:

\begin{abstract}
A meta da "escola cultural" vai além de meramente habilitar o homem a submeter-se às restrições de sua sociedade; na medida em que seja possível, ela procura libertá-lo de suas demandas irracionais e torná-lo mais capaz de desenvolver suas potencialidades e de assumir liderança na edificação de uma sociedade mais construtiva. ${ }^{65}$
\end{abstract}

A tensão entre saúde e conhecimento, normalidade e liberdade, que animou o trabalho todo de Freud, desaparece aqui; a qualificação "na medida em que seja possível" é o único traço que resta da contradição explosiva na meta. A "liderança na edificação de uma sociedade mais construtiva" deve ser combinada com o funcionamento normal da sociedade estabelecida. Essa filosofia é

${ }^{61}$ \{A orientação sociológica ou cultural\}

${ }^{62}$ FROMM, E. Psychoanalysis and religion, New Haven: Yale University Press 1950, p. 73 ss. [Edição brasileira: Psicanálise e religião. Rio de Janeiro: Livro Íbero-Americano Ltda., 1959, p. 88-91. Apontaremos abaixo uma série de problemas com essa versão, entretanto.]

${ }^{63}$ Ibid., p. 119. [Edição brasileira: Ibid., p. 138.]

${ }^{64}$ HORNEY, K. The neurotic personality of our time. New York: W. W. Norton and Co., 1937, p. 284. [Edição brasileira: A personalidade neurótica de nosso tempo. Rio de Janeiro: Editora Civilização Brasileira S.A., 1959, p. 205.] ${ }_{65}$ THOMPSON, loc. cit., p. 152. [Edição brasileira: THOMPSON, loc. cit., p. 139.] 
alcançada ao se dirigir a crítica contra fenômenos de superfície, enquanto aceitam-se as premissas básicas da sociedade criticada. Fromm dedica uma grande porção de seus escritos à crítica da "economia de mercado" e de sua ideologia, que põem grandes barreiras ao desenvolvimento produtivo. ${ }^{66}$ Mas aqui jaz o problema. As intuições [insights] críticas não levam a uma transvaloração dos valores da produtividade e do "self superior" - que são exatamente os valores da cultura criticada. O caráter da filosofia revisionista mostra-se na assimilação do positivo ao negativo, da promessa à sua traição. A afirmação absorve a crítica. O leitor é deixado com a convicção de que "valores mais elevados" podem e devem ser praticados dentro das mesmas condições que os traem; e eles podem ser praticados porque o filósofo revisionista os aceita em sua forma adaptada e idealizada - nos termos do Princípio de Realidade estabelecido. Fromm, que demonstrou as características repressivas da internalização como poucos outros analistas, reaviva a ideologia da internalização. A pessoa "adaptada" é culpada porque ela traiu o "self superior", os "valores humanos"; ela é, então, perseguida por "vazio interno e insegurança", a despeito de seu triunfo na "batalha pelo sucesso". Muito melhor está a pessoa que atingiu "a força interior e a integridade": embora possa ser pior sucedida que seu "vizinho inescrupuloso", "ela terá a segurança, o juízo e a objetividade que a tornarão muito menos vulnerável a mudanças da sorte e das opiniões dos outros, e que realçarão em muitas áreas sua habilidade para o trabalho construtivo" ${ }^{\prime 67} \mathrm{O}$ estilo sugere o Poder do Pensamento Positivo ${ }^{68}$ ao qual a crítica

${ }^{66}$ FROMM, Man for himself, loc. cit., esp. p. 67ss, 127-8. [Edição brasileira: Análise do homem, loc. cit., pp. 65-76, 114-5.]

${ }^{67}$ FROMM, Psychoanalysis and religion, loc. cit., p. 75. [Edição brasileira: Psicanálise e religião, loc. cit., p. 91. Essa versão faz acréscimos pouco toleráveis ao original. Traduz "security" por "mais segurança", "judgment" por "usará plenamente a sua razão"; "less" por "muito menos", e finalmente, "constructive work" por "viver construtivamente".]

${ }^{68}$ [Alusão a The power of positive thinking, livro escrito pelo Reverendo Norman Vincent Peale, e publicado em 1952. Edição brasileira: O poder do 
revisionista sucumbe. Não são os valores que são espúrios, mas sim o contexto em que eles são definidos e proclamados: "força interior" tem a conotação daquela liberdade incondicional que pode ser praticada mesmo no aprisionamento, que o próprio Fromm denunciou em sua análise da Reforma [Protestante].$^{69}$ Se os valores "força interior e integridade" devem ser outros e maiores do que os traços de caráter que a sociedade alienada espera de qualquer bom cidadão em seus negócios (caso em que eles servem apenas para sustentar a alienação), então eles devem pertencer a uma consciência que rompeu com a alienação, bem como com seus valores. Mas para essa consciência esses valores mesmos tornam-se intoleráveis, porque ela os reconhece como acessórios da escravização do homem. O "self superior" impera sobre os impulsos e aspirações domesticados do indivíduo que sacrificou e renunciou a seu "self inferior", não apenas à medida que o "self inferior" é incompatível com a civilização, mas à medida que ele é incompatível com a civilização repressiva. Essa renúncia talvez seja de fato um passo indispensável rumo ao progresso humano. Entretanto, a questão de Freud, de [saber] se os valores superiores da cultura não teriam sido atingidos a um custo muito alto para o indivíduo, deveria ser séria o suficiente ${ }^{70}$ para impedir o filósofo psicanalítico de pregá-los sem revelar seu conteúdo proibido, sem mostrar o que eles negaram ao indivíduo. O que essa omissão faz à teoria psicanalítica pode ser ilustrado contrastando as ideias de amor de Fromm e Freud. Fromm escreve:

O amor genuíno tem suas raízes na produtividade e pode chamar-se, apropriadamente, "amor produtivo". Sua essência é a mesma, quer se trate do amor da mãe pelo filho, quer de nosso amor pelo homem, ou do amor erótico entre dois indivíduos. [...] certos elementos

pensamento positivo, São Paulo, Cultrix, 2016.]

${ }^{69}$ Escape from freedom, New York: Rinehart and Co., 1941, p. 74ss. [Edição brasileira: O medo à liberdade. Rio de Janeiro: Zahar Editores, 1981, p. 62-94.] 70 ddeveria ser levada suficientemente a sério\} 
básicos podem ser considerados característicos de todas as formas de amor produtivo. São eles: cuidado, responsabilidade, respeito e conhecimento. ${ }^{71}$

Compare-se com essa formulação ideológica a análise de Freud da base e do subterrâneo instintuais do amor, do processo longo e doloroso no qual a sexualidade, com toda a sua perversidade polimórfica, é domada e inibida até que ela finalmente tornase suscetível à fusão com a ternura e a afeição - uma fusão que permanece precária e que nunca supera o bastante seus elementos destrutivos. Comparem-se com o sermão de Fromm sobre o amor os comentários quase incidentais de Freud em "Sobre a mais comum depreciação na vida amorosa":

não poderemos negar que o comportamento amoroso do homem na civilização de hoje traz geralmente a marca do tipo psiquicamente impotente. Apenas em poucas pessoas cultivadas as correntes terna e sensual são apropriadamente fundidas em uma só: o homem quase sempre sente sua atividade sexual limitada por seu respeito ante a mulher, e somente desenvolve potência sexual plena na presença de um objeto sexual mais baixo. ${ }^{72}$

${ }^{71}$ Man for himself, loc. cit., p. 98. [Edição brasileira: Análise do homem, loc. cit., p. 90. Marcuse retira de "cuidado, responsabilidade, respeito e conhecimento" o itálico que consta no original.]

${ }^{72}$ Collected papers, vol. IV. London: Hogarth Press, 1950, p. 210. [Edição brasileira: Sobre a mais comum depreciação na vida amorosa (contribuições à vida amorosa II). in: Obras completas, volume 9. São Paulo: Companhia das Letras, 2013, p. 355-6. Edição alemã: FREUD, Über die allgemeinste Erniedrigung des Liebeslebens. in: Gesammelte Werke, Band VIII. London: Imago Publishing, 1955, p. 85. Em português, "unserer heutigen Kulturwelt" literalmente: nosso mundo aculturado (ou cultivado) de hoje em dia - torna-se "no mundo civilizado de hoje", à semelhança da opção inglesa por "presentday civilization" (civilização de hoje em dia). "Typus" é "marca" em português e "type" (tipo) em inglês.] 
De acordo com Freud, o amor, em nossa cultura, pode e deve ser praticado como "sexualidade inibida na meta", com todos os tabus e restrições postos sobre ele por uma sociedade patriarcal monogâmica. Para além de suas manifestações legítimas, o amor é destrutivo e de modo algum conducente à produtividade e ao trabalho construtivo. $\mathrm{O}$ amor, levado a sério, é proscrito: "na vida civilizada de hoje não há mais lugar para o amor simples e natural entre dois seres humanos". ${ }^{73}$ Mas, para os revisionistas, produtividade, amor, felicidade e saúde fundem-se em grande harmonia; a civilização não causou quaisquer conflitos entre eles que a pessoa madura não poderia solucionar sem dano agravado.

\section{IV}

Uma vez que as aspirações humanas e sua realização são internalizadas e sublimadas no "self superior", as questões sociais tornam-se primariamente questões espirituais, e sua solução tornase uma tarefa moral. A concretude sociológica dos revisionistas revela-se como superfície: as batalhas decisivas são travadas na "alma" do homem. O autoritarismo atual e a "deificação da máquina e do sucesso" ameaçam as "posses espirituais mais preciosas" do homem. ${ }^{74} \mathrm{~A}$ minimização revisionista da esfera biológica, e especialmente do papel da sexualidade, desloca a ênfase não apenas do inconsciente para a consciência, do Id para o Eu, mas também

${ }^{73}$ Civilization and its disconents, loc. cit., p. 77, nota de rodapé. [Edição brasileira: O mal-estar na civilização, loc. cit., p. 70. Edição alemã: Das Unbehagen in der Kultur, loc. cit., p. 465. A versão inglesa verte "Leben des heutigen Kulturmenschen" por "civilized life" (vida civilizada), onde teria sido mais apropriada uma solução como a da edição brasileira: "vida do homem civilizado", ou "do homem aculturado". A edição brasileira verte "Menschenkinder" por "criaturas humanas", enquanto o inglês opta por "seres humanos".]

${ }^{74}$ FROMM, Psychoanalysis and religion, loc. cit., p. 119. [Edição brasileira: Psicanálise e religião, loc. cit., p. 138-9. A tradução já existente verte "possessions" por "possessões" e "deification" por "deifica-se".] 
das expressões pré-sublimadas para as expressões sublimadas da existência humana. Conforme a repressão da gratificação instintual retrocede ao plano de fundo e perde sua importância decisiva para a realização do homem, a profundidade da repressão societária é reduzida. Consequentemente, a ênfase revisionista sobre a influência das "condições sociais" no desenvolvimento da personalidade neurótica é sociológica e psicologicamente muito mais inconsequente que a "negligência" de Freud dessas condições. A mutilação revisionista da teoria dos instintos leva à tradicional desvalorização da esfera das necessidades materiais em favor das necessidades espirituais. A parte da sociedade no regramento do homem é assim minimizada; e a despeito da crítica aberta de algumas instituições, a sociologia revisionista aceita as fundações sobre as quais essas instituições repousam.

Também a neurose aparece como um problema essencialmente moral, e o indivíduo é responsabilizado pelo fracasso de sua autorrealização. A sociedade, é verdade, leva uma parte da acusação, mas, em última análise, é o próprio homem que é culpado:

\begin{abstract}
Olhando para a sua criação, ele pode dizer, verdadeiramente, que é boa. Mas olhando para si mesmo, o que pode dizer? [...] Embora nós tenhamos criado coisas maravilhosas, não conseguimos fazer de nós mesmos seres para os quais esse esforço tremendo parecesse ser digno. A nossa vida não é de fraternidade, felicidade, contentamento, mas de caos espiritual e perplexidade $[\ldots] .{ }^{75}$
\end{abstract}

${ }^{75}$ FROMM, Psychonalysis and religion, loc. cit., p. 1. [Edição brasileira: Psicanálise e religião, p. 3-4. Marcuse não indica uma passagem de parágrafo entre a primeira e a segunda sentença. Na tradução já existente, aparecem novos e mais graves problemas. A tradutora acrescenta frases inexistentes no original, muda significativamente alguns dos termos, transforma afirmações em interrogativas. Fromm escreve: "Looking at his creation, he can say, truly, it is good". O Fromm brasileiro sobe ao púlpito, e afirma: "Olhando para a sua criação, como Deus no sétimo dia de descanso, ele também tem o direito de 
A desarmonia entre sociedade e indivíduo é declarada e deixada de lado. O que quer que a sociedade faça com o indivíduo, ela não impede nem ele nem o analista de se concentrar na personalidade total e seu desenvolvimento produtivo. De acordo com Horney, a sociedade cria "certas dificuldades típicas [...] que, acumuladas, podem levar à formação da neurose" ${ }^{\prime 7}$ De acordo com Fromm, o impacto negativo da sociedade sobre o indivíduo é mais sério, mas isso é apenas um desafio para se praticar o amor produtivo e o pensamento produtivo. A decisão repousa na "capacidade" do homem "para levar a sério a si mesmo, a sua vida e a sua felicidade; em sua disposição para enfrentar o problema moral seu e de sua sociedade. Está em sua coragem para ser ele mesmo e de ser para si mesmo". ${ }^{77}$ No período do totalitarismo,

sentir que realizou uma grande obra". Fromm pergunta: "But looking at himself what can he say?". O Fromm brasileiro, piedoso, interroga-se: "Mas se olhar para si mesmo, o que terá ele de confessar?". Fromm afirma candidamente: "we have failed to make of ourselves beings for whom this tremendous effort would seem worthwhile". O Fromm brasileiro substitui o esforço da tradução pela realização do desejo, e opta pela questão retórica: "teremos merecido realizações tão grandiosas?". Fromm acusa uma "life ... of spiritual chaos and bewilderment"; o Fromm brasileiro, cheio de beatitude existencial, opta pela "existência ... num caos espiritual e num estado de confusão fronteiriça à loucura".]

${ }^{76}$ The neurotic personality of our time, loc. cit., p. 284. [Edição brasileira: A personalidade neurótica de nosso tempo, loc. cit., p. 205.]

${ }^{77}$ Man for himself, loc. cit., p. 250. [Edição brasileira: Análise do homem, loc. cit., p. 211. Atente-se para a polissemia da expressão que dá título ao livro de Fromm em sua versão original e que se repete ao final da citação - "homem [...] para si mesmo". A opção do tradutor brasileiro anterior é a de verter "to be himself and for himself" por "ser ele mesmo e por si mesmo", o que parece conotar certa capacidade de permanecer fiel a si e de suportar isolamento. Essa não é uma interpretação totalmente estranha ao argumento de Fromm, mas seria talvez uma alternativa melhor caso o último fragmento dissesse "by himself" e não "for himself". Fromm advoga por uma solução comunitária para o problema do isolamento, solução essa na qual deveriam conciliar-se autonomia individual e relação solidária a outros. Por isso, preferimos "para 
no qual o indivíduo tornou-se tão inteiramente o sujeito-objeto da manipulação que, para a pessoa "saudável e normal", até a ideia de uma distinção entre ser "para si" [for himself] ou "para outros" tornou-se totalmente sem sentido; no qual o aparato onipotente pune a não-conformidade real com ridicularização e derrota - em tal situação, o filósofo neofreudiano diz ao indivíduo para ser ele mesmo e para si mesmo [for himself]. Para os revisionistas, ${ }^{78}$ o fato bruto da repressão societária transformou-se em um "problema moral" - assim como na filosofia conformista de todas as épocas. E como o fato clínico da neurose torna-se "em última instância, um sintoma de fracasso moral", ${ }^{79}$ a "cura psicanalítica da alma" tornase educação para atingir uma atitude "religiosa". 80

A fuga da psicanálise na ética internalizada e na religião é a consequência da revisão da teoria psicanalítica. Se a "ferida" na existência humana não opera na constituição biológica do homem, e se ela não é causada e sustentada pela própria estrutura da civilização, então a dimensão de profundidade é removida da psicanálise, e o conflito (ontogenético e filogenético) entre forças pré-individuais e supraindividuais aparece como um problema do comportamento racional ou irracional, moral ou imoral, dos

si", que conota o elemento reflexivo da relação do homem a si mesmo e, também, da humanidade a si mesma. Tem-se que levar em conta, inclusive, que no contexto do qual a citação foi extraída, "man" significa provavelmente "o homem em geral", "a humanidade", e não o indivíduo singular. Em outros contextos, a versão por "a favor de si mesmo", e mesmo "por si", poderia ser também adequada.]

${ }^{78}$ \{o revisionista\}

${ }^{79}$ Man for himself, loc. cit., p. VIII. [Edição brasileira: Análise do homem, loc. cit., p. 10. A tradução existente verte "failure" por "falência". Preferimos a noção literal, "fracasso", que aponta para a relação negativa entre potencialidades humanas e condições de vida - o fracasso (socialmente condicionado) em tornar-se aquilo que se poderia ser, e não a desagregação da conduta ou o relapso na imoralidade.]

${ }^{80}$ Psychoanalysis and religion, p. 76. [Edição brasileira: Psicanálise e religião, loc. cit., p. 91.] 
indivíduos conscientes. A substância da teoria psicanalítica não repousa simplesmente na descoberta do papel do inconsciente, mas na descrição da sua dinâmica instintual específica, das vicissitudes dos dois instintos básicos. Apenas a história dessas vicissitudes revela a plena profundidade da opressão que a civilização impõe ao homem. Se a sexualidade não desempenha o papel constitutivo que Freud atribuiu a ela, então não há conflito fundamental entre o Princípio do Prazer e o Princípio de Realidade; a natureza instintual do homem é "purificada" e adaptada a atingir, sem mutilação, a felicidade socialmente útil e reconhecida. É precisamente porque viu na sexualidade o representante do Princípio do Prazer integral que Freud foi capaz de descobrir as raízes comuns das felicidades "geral" e neurótica em uma profundidade muito abaixo de toda experiência individual, e reconhecer uma repressão primária "constitucional" subjazendo a toda repressão conscientemente experimentada e administrada. Ele levou essa descoberta muito a sério - a sério demais para identificar a felicidade com sua sublimação eficiente \{em amor produtivo e outras\} atividades produtivas. Por isso, ele considerou uma civilização orientada à realização da felicidade como uma catástrofe, como o fim de toda civilização. Para Freud, todo um mundo ${ }^{81}$ separa\{va\} liberdade e felicidade de seus simulacros ${ }^{82}$ [pseudos], que são praticados e pregados em uma civilização repressiva. Os revisionistas não veem problema nisso. Como eles espiritualizaram a liberdade e a felicidade, podem dizer que "o problema da produção foi virtualmente resolvido":83 "Nunca antes o homem esteve tão perto da realização de suas mais caras esperanças quanto hoje. Nossas descobertas científicas e conquistas técnicas permitemnos visualizar o dia em que a mesa estará posta para todos que

\footnotetext{
${ }^{81}$ \{um vão [gulf] enorme\}

82 \{da pseudoliberdade e pseudofelicidade\}

${ }^{83}$ FROMM, Man for himself, loc. cit., p. 140. [Edição brasileira: Análise do homem, loc. cit., p. 124. Marcuse não acrescenta o itálico constante no original para a palavra "produção".]
} 
queiram comer $[\ldots]]^{\prime}{ }^{84}$ Essas declarações são verdadeiras - mas apenas à luz de sua contradição: precisamente porque o homem nunca chegou tão perto da realização de suas esperanças, ele nunca esteve tão estritamente impedido de realizá-las; precisamente porque nós podemos visualizar a satisfação universal de necessidades individuais, os obstáculos mais fortes são postos no caminho de tal satisfação. Apenas se a análise sociológica elucida essa conexão ela vai além de Freud; de outro modo, ela é apenas um adorno inconsequente, adquirido ao custo de uma mutilação da teoria dos instintos de Freud. Freud havia estabelecido uma conexão substancial entre liberdade humana e felicidade, de um lado, e sexualidade, de outro. Esta última provia a base e a fonte primárias das outras, e ao mesmo tempo a base para a sua restrição necessária na civilização. A solução revisionista do conflito através da espiritualização da liberdade e da felicidade demandou o enfraquecimento daquela conexão. Não importa quanto os achados terapêuticos tenham motivado a redução teórica do papel da sexualidade: essa redução era indispensável para a filosofia reducionista..$^{85}$

(Aqui segue uma breve discussão do conceito de sexualidade neofreudiano e do complexo de Édipo: na interpretação revisionista, essa esfera é apresentada sem expor as zonas de perigo instintuais da sociedade. $)^{86}$

${ }^{84}$ FROMM, Psychoanalysis and religion, p. 1. [Edição brasileira: Psicanálise e religião, loc. cit., p. 3. Desta vez, a tradução brasileira anterior opta por realizar a utopia que a versão inglesa apenas indica como próxima. O original afirma: "Never before has man come so close to the fulfillment of his most cherished hopes as today". Em português, encontramos: "Jamais anteriormente havia o homem atingido, como hoje, a realização das suas esperanças mais queridas". O Fromm anglófono, cortês, espera que a comida esteja posta à mesa: "the table will be set for all who want to eat". O Fromm brasileiro, mais ávido de fome, talvez, afirma simplesmente: "todos terão o que comer".]

${ }^{85}$ \{Descobertas terapêuticas podem ter motivado a redução teórica do papel da sexualidade; mas tal redução era, de todo modo, indispensável para a filosofia reducionista\}

${ }^{86}$ [Este segmento aparece assim mesmo, em tamanho reduzido e entre 


\begin{abstract}
\{Os problemas sexuais, embora possam por vezes predominar no quadro sintomático, não são mais considerados o centro dinâmico das neuroses. As dificuldades sexuais são o efeito, e não a causa, da estrutura de caráter neurótica. Problemas morais, de outra parte, ganham importância. ${ }^{87}$
\end{abstract}

Essa concepção faz bem mais do que minimizar o papel da libido; ela reverte a direção interior da teoria freudiana. Em lugar algum isso fica mais claro do que na reinterpretação de Fromm do complexo de Édipo, que tenta "traduzi-lo da esfera do sexo para a das relações interpessoais". ${ }^{88} \mathrm{O}$ ponto principal dessa "tradução" é que a essência do desejo incestuoso não é "anseio sexual", mas o desejo de continuar protegido, seguro - uma criança. "O feto vive com a mãe e da mãe, e o ato de nascimento é apenas um passo na direção da liberdade e da independência". É verdade - mas a liberdade e a independência a serem conquistadas (se é que o serão) é afligida com carência, resignação e dor; e o ato do nascimento é o primeiro e mais terrível passo na direção contrária da satisfação e da segurança. A interpretação ideológica que Fromm faz do complexo de Édipo implica a aceitação da infelicidade da liberdade, de sua separação com relação à satisfação; a teoria de Freud implica que o desejo edípico é o eterno protesto infantil contra essa separação protesto, não contra a liberdade, mas contra a liberdade dolorosa, repressiva. Reciprocamente, o desejo edípico é o eterno desejo

colchetes, no texto original. Como não há indicação de intervenção dos editores, supõe-se que a nota seja do próprio Marcuse. O segmento seguinte, entre chaves, foi acrescentado ao epílogo de Eros e civilização.]

${ }^{87}$ \{HORNEY, K. New ways in psychoanalysis. New York: W. W. Norton, 1939, p. 10. [Edição brasileira: Novos rumos na psicanálise. Rio de Janeiro: Editora Civilização Brasileira S.A., 1966, p. 13.]\}

${ }^{88}$ \{Psychoanalysis and religion, p. 79ss. Veja-se também a interpretação mais sofisticada de Fromm em The forgotten language. New York: Rinehart, 1951, pp. 231-235. [Edições brasileiras: Psicanálise e religião, loc. cit., pp. 95-99; A linguagem esquecida. Rio de Janeiro: Zahar Editores, 1969, pp. 169-172.]\} 
infantil pelo arquétipo da liberdade: liberdade da carência. E como o instinto sexual (não reprimido) é o portador biológico desse arquétipo da liberdade, o desejo edípico é essencialmente "anseio sexual". Seu objeto natural é, não simplesmente a mãe qua mãe, mas a mãe qua mulher - princípio feminino de gratificação. Aqui o Eros da receptividade, repouso, da satisfação integral e sem dor está mais próximo do instinto de morte (retorno ao útero); o princípio do prazer está mais próximo do princípio do Nirvana. ${ }^{89}$ Eros luta aqui a sua primeira batalha contra tudo que o princípio de realidade representa: contra o pai, contra a dominação, a sublimação, a resignação. Então, gradualmente, liberdade e realização estão sendo associadas com esses princípios paternos; a liberdade da carência é sacrificada em nome da independência moral e espiritual. É em primeiro lugar o "anseio sexual" pela mulher-mãe que ameaça a base psíquica da civilização; é o "anseio sexual" que torna o conflito edípico o protótipo dos conflitos instintuais entre o indivíduo e sua sociedade. Se o desejo edípico não fosse em essência nada além de desejo de proteção e segurança ("medo à liberdade") ${ }^{90}$ se a criança desejasse apenas segurança intolerável, e não um prazer intolerável, então o complexo de Édipo de fato configuraria um problema educacional. Como tal, ele pode ser tratado sem expor as zonas de perigo instintuais da sociedade.\}

O mesmo resultado benéfico obtém-se pela rejeição do Instinto de Morte. A hipótese \{de Freud\} do Instinto de Morte e seu papel na agressão civilizada lançou luz sobre um dos enigmas negligenciados da civilização: ela revelou o elo inconsciente oculto que liga o oprimido a seus opressores, os soldados a seus

\footnotetext{
${ }^{89}$ [Como este segmento consta apenas na segunda versão do texto de Marcuse, os conceitos freudianos mencionados aparecem sem letras maiúsculas, à diferença da grafia adotada na versão da revista Dissent.]

${ }^{90}$ [Aqui, Marcuse escreve "escape from freedom", o título do livro de Fromm que foi vertido para o português como "o medo à liberdade". Embora a tradução mais literal seja algo como "fuga da liberdade", preferimos manter o teor alusivo da expressão.]
} 
generais, os indivíduos a seus senhores. As destruições ${ }^{91}$ maciças que marcaram o progresso da civilização dentro do quadro da dominação foram perpetuadas, face à sua possível abolição, pela concordância instintual de parte das vítimas e instrumentos humanos com seus executores. Freud escreveu durante a $\{\mathrm{P}\}$ rimeira Guerra Mundial:

pensem nas brutalidade, crueldade e mendacidade colossais que hoje se permite que espalhem-se pelo mundo civilizado. Os senhores acreditam mesmo que um punhado de representantes e corruptores de homens sem princípios teria conseguido libertar tanto mal latente, se os seus milhões de seguidores não fossem também culpados? ${ }^{92}$

Mas os impulsos que essa hipótese assume são incompatíveis com a filosofia moralista do progresso defendida pelos revisionistas. Karen Horney declara sucintamente a posição revisionista:
A ideia de Freud (de um Instinto de Morte) ${ }^{93}$ supõe que a motivação última da hostilidade ou da destrutividade reside no impulso de destruir. Desse modo, ele transforma a nossa crença de que destruímos para viver em seu oposto: nós vivemos para destruir. ${ }^{94}$

Essa interpretação [rendering] da concepção de Freud é incorreta. Ele não presumiu quenós vivemos para destruir;oinstinto de destruição opera contra os Instintos de Vida ou a serviço deles.

\footnotetext{
91 \{A destruição\}

92 A general introduction to psychoanalysis, loc. cit., pp. 130-131. [Edição brasileira: Conferências introdutórias à psicanálise, loc. cit., p. 197-8.] 93 [Este acréscimo é do próprio Marcuse.]

${ }^{94}$ New ways in psychoanalysis, loc. cit., pp. 130-131. [Edição brasileira: Novos rumos na psicanálise, loc. cit., p. 108. As mesmas páginas valem para as citações que aparecem logo em seguida no texto.]
} 
Além disso, não é a destruição per se que é o objetivo do Instinto de Morte, mas a eliminação da necessidade de destruição. De acordo com Horney, nós desejamos destruir porque "somos ou nos sentimos ameaçados, humilhados, abusados", porque desejamos defender "nossa segurança e nossa felicidade ou o que aparece assim para nós." Não era necessária teoria psicanalítica alguma para chegar a essas conclusões, com as quais a agressão individual e nacional tem sido justificada desde tempos imemoriais. Ou nossa segurança é realmente ameaçada, e então nosso desejo de destruir é uma reação racional e sensível; ou nós apenas "sentimos" que ela é ameaçada, e então as razões individuais e supraindividuais para esse sentimento têm de ser exploradas.

A rejeição revisionista do Instinto de Morte é acompanhada de um argumento que de fato parece apontar as implicações "reacionárias" da teoria freudiana, em contraste com a orientação sociológica progressista dos revisionistas: a admissão de Freud de um Instinto de Morte

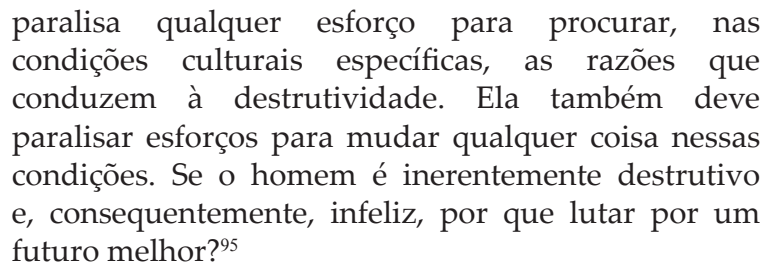

$\mathrm{O}$ argumento revisionista minimiza o grau em que, na teoria freudiana, os impulsos são modificáveis, sujeitos às "vicissitudes" da história. O Instinto de Morte e seus derivados não são exceção. Nós sugerimos que a energia do Instinto de Morte não deve "paralisar" necessariamente os esforços para se obter um "futuro melhor" - pelo contrário, tais esforços são paralisados pelas restrições sistemáticas que a civilização põe aos Instintos de Vida, e por sua consequente inabilidade em "ligar" a agressão

${ }^{95}$ Ibid., p. 132. [Ibid., pp. 109-10.] 
efetivamente. A realização de um "futuro melhor" envolve bem mais do que a eliminação das más características do "mercado", da "impiedade", da competição etc. ${ }^{96}$ - ela envolve uma mudança fundamental na estrutura instintual, bem como na estrutura cultural. A aspiração a um futuro melhor é "paralisada", não pela ciência [awereness] de Freud dessas implicações, mas por sua "espiritualização" neofreudiana, que encobre ${ }^{97} \mathrm{o}$ vão que separa o presente do futuro. Freud de fato não acreditava em mudanças sociais prospectivas que permitiram alterar a natureza humana suficientemente para liberar o homem da opressão externa e interna. Entretanto, ele tentou mostrar que seu "fatalismo" não era desprovido de qualificações. ${ }^{98}$

A mutilação da teoria dos instintos completa a inversão da teoria freudiana. A direção interior dessa última era (em aparente contraste com o "programa terapêutico" do Id ao Eu) da consciência ao inconsciente, da personalidade à infância, dos processos individuais aos genéricos. A teoria movia-se da superfície à profundidade, da pessoa "acabada" e condicionada às suas fontes e recursos. Esse movimento era essencial para a crítica ${ }^{99}$ da civilização de Freud: apenas através da "regressão" para detrás ${ }^{100}$ das formas mistificadoras do indivíduo maduro e sua existência pública e privada ele descobriu a negatividade básica dessas formas nas fundações sobre as quais elas repousam. Além disso, apenas ao empurrar essa regressão crítica de volta à camada biológica mais profunda Freud pôde elucidar o conteúdo oculto ${ }^{101}$ das formas mistificadoras e, ao mesmo tempo, o escopo completo da repressão civilizada. Identificar a energia dos Instintos de Vida como libido significou definir sua gratificação em contradição com

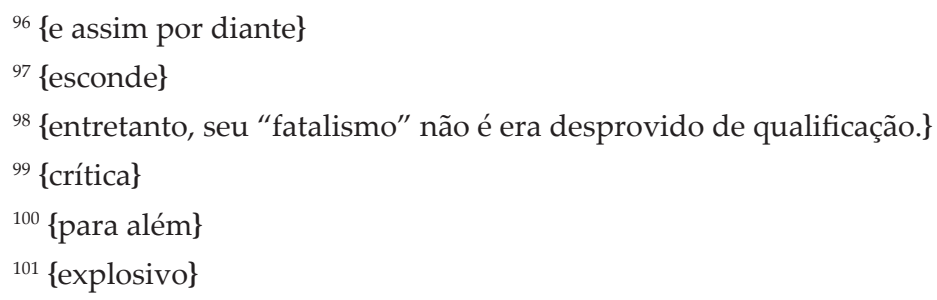


o transcendentalismo espiritual: a noção de felicidade e liberdade de Freud é eminentemente crítica à medida que é materialista protesta contra a espiritualização da carência. Os neofreudianos revertem essa direção interior da teoria de Freud, deslocando a ênfase do organismo para a personalidade, das fundações materiais para os valores ideais. Essas várias revisões agora aparecem em sua consistência lógica: uma acarreta a outra. ${ }^{102} \mathrm{O}$ conjunto pode ser resumido da seguinte forma: a "orientação cultural" encontra as instituições e relações societárias como produtos acabados, na forma de entidades objetivas - fatos dados, em vez de feitos. Sua aceitação nessa forma demanda o deslocamento da ênfase psicológica da infância para a maturidade, pois apenas no nível da consciência desenvolvida o ambiente cultural torna-se definível como determinando o caráter e a personalidade acima [over and above] do nível biológico. Reciprocamente, apenas \{com\} a subestimação do nível biológico, ${ }^{103} \mathrm{com}$ a mutilação da teoria dos instintos, a personalidade torna\{-se\} definível em termos de valores culturais objetivos separados do solo repressivo que nega sua realização. Para apresentar esses valores como liberdade e realização, eles têm que ser expurgados do material do qual são feitos, e a luta por sua realização tem de ser transformada em uma luta espiritual e moral. Os revisionistas não insistem, como Freud, no valor de verdade persistente das necessidades instintuais que devem ser "quebradas" para que o ser humano possa funcionar em relações interpessoais. Ao abandonar a insistência nisso, insistência de que a teoria psicanalítica extraiu todos as suas intuições [insights] críticas, os revisionistas rendem-se às características negativas do mesmo Princípio de Realidade que eles criticam tão eloquentemente.

\footnotetext{
102 \{Suas várias revisões são logicamente consistentes: cada qual acarreta a seguinte\}

103 \{fator biológico\}
} 


\section{As implicações humanas do "radicalismo" instintivista: uma réplica a Herbert Marcuse ${ }^{104}$}

\section{Erich Fromm}

Estou feliz por ter a oportunidade de responder ao artigo de Herbert Marcuse sobre "As implicações sociais do revisionismo freudiano"105, [publicado] na última edição desta revista. É assim em parte porque Marcuse me destaca como sendo um representante da teoria "revisionista" e acusa-me de ter passado de um pensador radical e crítico da sociedade a um porta-voz da adaptação e do status quo. Mais importante [que isso]: eu quero responder Marcuse porque ele toca em alguns dos problemas mais significativos da teoria psicanalítica e de suas implicações sociais - problemas que são de interesse geral para qualquer investigador [student] da sociedade contemporânea.

Entretanto, eu não posso seguir o procedimento de Marcuse de amontoar vários escritores "revisionistas". Posso falar apenas por mim mesmo, e isso por uma razão muito boa: embora haja certos pontos que os escritos de Horney e Sullivan têm em comum com os meus, eles diferem fundamentalmente com respeito justamente aos problemas com os quais Marcuse lida em seu artigo. (Eu mesmo apontei várias diferenças básicas em relação a Sullivan em Psicanálise da sociedade contemporânea [The sane society]). ${ }^{106}$ Esse amontoamento tem o resultado infeliz de que Marcuse sustenta seu argumento contra mim citando Horney ou

\footnotetext{
104 Tradução de Matheus Romanetto. Copyright c 1955 by Erich Fromm; Copyright c 2019 by Erich Fromm Estate (fromm-estate@fromm-online.com).

${ }^{105}$ [Fromm cita o título do artigo sem as aspas ao redor de "revisionismo", tal como aparecem na edição original do texto.]

${ }^{106}$ [Edição brasileira: Psicanálise da sociedade contemporânea. Rio de Janeiro: Zahar Editores, 1974.]
} 
Sullivan sempre que não existe passagem em meus escritos que serviria para [esse] propósito.

O artigo de Marcuse contém duas teses principais. Primeiro, a de que a teoria freudiana é não apenas correta psicologicamente, mas [também] uma teoria radical em sua crítica explícita e implícita da sociedade. Segundo, a de que minhas próprias teorias são filosoficamente idealistas, aconselhando adaptação à sociedade alienada atual e fazendo uma crítica dessa sociedade apenas da boca para fora.

Tomemos essas duas afirmações, uma após a outra:

De fato, é verdade que Freud foi um crítico da sociedade, mas sua crítica não era da sociedade capitalista contemporânea, e sim da civilização como tal. A felicidade, para Freud, é a satisfação do instinto sexual, especificamente do desejo de livre acesso a todas as fêmeas disponíveis. $\mathrm{O}$ homem primitivo, de acordo com Freud, tem ainda que lidar com muito poucas restrições à satisfação desses desejos básicos. Além disso, ele pode aliviar sua agressão. É a repressão desses desejos que conduz à civilização continuamente crescente e, ao mesmo tempo, a uma incidência crescente de neurose. "O homem civilizado", diz Freud, "trocou uma parte de suas chances de felicidade por uma medida de 'segurança'". ${ }^{107}$ $\mathrm{O}$ conceito de homem de Freud era o mesmo que subjaz à maior parte da especulação antropológica do século XIX. O homem, tal como é moldado pelo capitalismo, é tomado pelo homem natural, [e] então, o capitalismo, pela forma de sociedade que corresponde às necessidades da natureza humana. Essa natureza é competitiva, agressiva, egoísta. Ela procura sua realização na vitória sobre os seus concorrentes. Na esfera da biologia, isso foi demonstrado por

${ }^{107}$ FREUD, Civilization and its discontents, loc. cit., p. 92. [Edição brasileira: $\mathbf{O}$ mal-estar na civilização, loc. cit., p. 82. Edição alemã: Das Unbehagen in der Kultur, loc. cit., p. 474. Em alemão, lê-se: "Der Kulturmensch hat für ein Stück Glücksmöglichkeit in Stück Sicherheit eingetauscht". A tradução inglesa é mais fiel à denotação que à conotação neste caso: verte "ein Stück Glücksmöglihkeit" por "some part of his chances of happiness", enquanto a versão brasileira diz apenas "um tanto de felicidade", conservando o tom casual da frase, mas abrindo mão da especificação - possibilidade de felicidade.] 
Darwin em seu conceito da sobrevivência dos mais aptos; na esfera da economia, no conceito do homo economicus, sustentado pelos economistas clássicos. Na esfera da psicologia, Freud expressou a mesma ideia a respeito do homem, baseado na competitividade resultante da natureza do instinto sexual. "Homo homini lupus [O homem é o lobo do homem]; quem tem coragem de contestá-lo, face a todas as evidências de sua própria vida e da história?"108, pergunta Freud. A agressividade do homem, pensa Freud, tem duas fontes: uma, a aspiração inata à destruição (instinto de morte); a outra, a frustração de seus desejos instintuais, imposta a ele pela civilização. Embora o homem possa canalizar parte de sua agressão contra si mesmo, por meio do Super-eu, e embora uma minoria possa sublimar seu desejo sexual em amor fraterno, a agressividade permanece inerradicável. Os homens sempre competirão uns com os outros e se atacarão mutuamente, se não por coisas materiais, então pelas

\begin{abstract}
prerrogativas $\mathrm{n}$ [o âmbito d]as relações sexuais, que devem excitar o mais forte rancor e a mais violenta inimizade entrehomense mulheres que, de outromodo, são iguais. Suponhamos que isso também devesse ser removido mediante a instituição da completa liberdade na vida sexual, de modo que a família, célula germinal da civilização, deixasse de existir; não se pode, é verdade, prever os novos caminhos pelos quais o desenvolvimento cultural poderia proceder, mas uma coisa se estaria fadado a esperar: que esse traço não apagável da natureza humana a acompanharia a onde quer que ele conduzisse ${ }^{109}$.
\end{abstract}

${ }^{108}$ Ibid., p. 85. [Edição brasileira: O mal-estar na civilização, loc. cit., p. 77. Edição alemã: Das Unbehagen in der Kultur, loc. cit., p. 471. O original diz: "Homo homini lupus: wer hat nach allen Erfahrungen des Lebens und der Geschichte den Mut, diesen Satz zu bestreiten?". O inglês verte para "evidence" (evidência), e o português para "aprendizado", o que numa tradução mais literal de "Erfahrungen" constaria como "experiências".]

109 Ibid., p. 89. [Edição brasileira: O mal-estar na civilização, loc. cit., p. 80. 
Como, para Freud, o amor é em sua essência desejo sexual, ele é compelido a assumir uma contradição entre amor e coesão social. O amor, de acordo com ele, é por sua própria natureza egoísta e antissocial, e o senso de solidariedade e de amor fraterno não são sentimentos primários enraizados na natureza do homem, mas desejos sexuais inibidos na meta.

Com base em seu conceito de homem - o de seu desejo inerente por satisfação sexual ilimitada e de sua destrutividade -, Freud deve chegar a uma imagem do conflito necessário entre toda civilização e a saúde mental e a felicidade. O homem primitivo é saudável e feliz porque ele não tem seus instintos básicos frustrados, mas faltam-lhe as benesses da cultura. O homem civilizado é mais seguro, frui a arte e a ciência, mas está fadado a ser neurótico por causa da frustração contínua de seus instintos que é imposta pela civilização.

Para Freud, a vida social e a civilização estão essencial e necessariamente em contraste com as necessidades da natureza humana, tal como ele a vê, e o homem é confrontado com a alternativa trágica entre felicidade baseada na satisfação irrestrita dos instintos e segurança e conquistas culturais baseadas na frustração instintual - [alternativa essa] conducente, portanto, à neurose e a todas as outras formas de doença [sickness] mental. A civilização, para Freud, é o produto da frustração instintual e, então, a causa da doença [illness] mental. É óbvio que, do ponto de vista de Freud, não há esperança de nenhum aperfeiçoamento fundamental da sociedade, pois nenhuma ordem social pode transcender o conflito

Edição alemã: Das Unbehagen in der Kultur, loc. cit., p. 473. Onde o alemão diz "Mißgunst", a edição brasileira opta por "desgosto", e a inglesa, por "rancour" (rancor). O inglês conserva a neutralidade de "Menschen" dizendo "men and women" (homens e mulheres), enquanto o português opta por "seres". O verbo "aufheben" torna-se "to remove" (remover) em inglês e "suprimir" em português. Finalmente, "Kultur" verte-se por "culture" (cultura) em inglês e "civilização" em português. A questão é de certo modo nominal, já que o próprio Freud afirmou, em $\mathbf{O}$ futuro de uma ilusão, que não diferenciava os termos.] 
necessário e inevitável entre as reivindicações da natureza humana e da felicidade, de um lado, e as reivindicações da sociedade e da civilização, de outro. Será essa uma teoria radical, uma crítica radical da sociedade alienada?

Freud faz uma crítica específica da sociedade contemporânea apenas com respeito a um ponto. Ele a critica por sua moralidade sexual demasiado estrita, que produz neurose em um grau maior do que o necessário. Essa crítica não está de modo algum preocupada com a estrutura socioeconômica da sociedade, mas apenas com a sua moralidade sexual, e ela é parte da mesma atitude de tolerância que nós encontramos na educação, na criminologia e na psiquiatria modernas (como eu sinalizei em meu artigo "A condicionalidade social da terapia psicanalítica", publicado em Zeitschrift für Sozialforschung, v. IV, 1935, que Marcuse menciona em seu artigo). Essa crítica da sociedade contemporânea está no mesmo espírito de todas as proposições reformistas.

A segunda premissa de Marcuse é a suposição de que a teoria dos instintos de Freud é uma teoria radical, porque ela é materialista e vai às raízes. Eu acho espantoso que Marcuse cometa o erro de denominar "radical" uma teoria que está inteiramente no mesmo espírito que a do materialismo burguês do século XIX. Como qualquer um que tenha lido a biografia de Freud escrita por [Ernest] Jones ${ }^{110}$ pode ver muito claramente, Freud foi altamente influenciado por fisiólogos materialistas como Brücke, du BoisReymond e outros. De acordo com suas posições, as pistas para todos os fenômenos do homem eram físico-químicas, e a teoria da libido de Freud foi construída sobre essa base. É esse tipo de materialismo que havia sido superado pelo materialismo histórico de Marx, no qual a atividade da personalidade total em suas relações com a natureza e com outros membros da sociedade é o ponto arquimediano a partir do qual a história e as mudanças sociais são explicadas.

${ }^{110}$ [JONES, E. The life and work of Sigmund Freud. New York: Basic Books, 1981. 3 volumes. Edição brasileira: A vida e a obra de Sigmund Freud. Rio de Janeiro: Imago, 1989. 3 volumes.] 
Partindo desse tipo de materialismo, chega-se a uma teoria da natureza humana que não é, de maneira alguma, "ideológica". Tal teoria está baseada no fato da "situação humana", nas condições específicas da existência humana. O homem, tendo ciência de si mesmo [awareness of himself], transcendeu o mundo natural; ele é vida ciente de si mesma [aware of itself]. Ao mesmo tempo, ele continua sendo uma parte da natureza, e dessa contradição seguemse suas paixões e aspirações básicas, a necessidade de relacionar-se com outros, a necessidade de transcender seu papel como criatura através da criação (ou destruição), a necessidade de ter um senso de identidade e um quadro de orientação ou devoção. Essas necessidades podem ser satisfeitas [fulfilled] de várias maneiras - a diferença entre essas maneiras é a diferença entre saúde mental e doença [illness], entre felicidade e infelicidade. Entretanto, elas devem ser satisfeitas [fulfilled] para que ohomem nãose torneinsano. De outra parte, a satisfação [fulfillment] de todas as necessidades instintuais, incluindo o sexo, não é uma condição suficiente para a felicidade - nem mesmo para a sanidade. O conceito de existência humana não é menos real do que o dos instintos, e não é idealista; ele é mais amplo e é concebido em termos de atividade e prática, em vez de uma substância fisiológica específica.

Acreditar que uma teoria que demanda maior liberdade para o instinto sexual é, por essa razão mesma, uma teoria radical, é um erro que pode ser entendido como resultado de um materialismo mal compreendido, ou como uma reação ao fato de que grupos conservadores e reacionários eram adeptos de uma moralidade sexual repressiva e estrita na primeira parte do século XX. Por isso parece que a emancipação sexual foi um passo radical rumo à emancipação em relação à opressão. Entretanto, a atitude dos nazistas frente à liberdade sexual foi evidência suficientemente concreta de que essa suposição estava errada. Os nazistas, muito longe de seguirem a ideologia reacionária nesse ponto, favoreceram a promiscuidade sexual e foram extraordinariamente permissivos em seu código [de conduta] sexual. Mas o exemplo dos nazistas não é nem mesmo necessário. A satisfação sexual ilimitada é apenas parte de um traço característico do capitalismo do século 
XX: a necessidade de consumo em massa, o princípio de que todo desejo deve ser satisfeito imediatamente, de que nenhum desejo deve ser frustrado.

O princípio de que desejos devem ser satisfeitos sem muita espera também determinou o comportamento sexual, especialmente desde o fim da Primeira Guerra Mundial. Uma forma vulgar de freudismo mal compreendido costumava fornecer as racionalizações apropriadas. A ideia era a de que neuroses resultam de aspirações sexuais "reprimidas", de que frustrações eram "traumáticas", e de que quanto menos você reprimisse, mais saudável você seria. Até mesmo os pais estavam ansiosos para dar às suas crianças tudo que quisessem, por temor de que elas se tornassem frustradas e adquirissem um "complexo". Infelizmente, muitas dessas crianças, assim como seus pais, pousaram no divã do analista, desde que pudessem pagar por isso.

A ganância por coisas e a incapacidade de postergar a satisfação de desejos como algo característico do homem moderno foi enfatizado por observadores argutos, como Max Scheler e Bergson. Ela recebeu sua expressão mais aguda nas mãos de Aldous Huxley em Admirável mundo novo. Entre os slogans pelos quais os adolescentes no Admirável Mundo Novo são condicionados, um dos mais importantes é: "Nunca deixe para amanhã a diversão que puder gozar hoje". Ele é martelado neles: "duzentas repetições, duas vezes por semana, dos quatorze aos dezesseis anos e meio". Essa realização instantânea de desejos é sentida como felicidade. "Todos são felizes hoje em dia" é outro dos slogans do Admirável Mundo Novo; as pessoas "conseguem o que desejam e nunca desejam o que não podem conseguir". Essa necessidade de consumo imediato de mercadorias está acoplada à necessidade de consumação imediata de desejos sexuais no Admirável Mundo Novo, assim como em nosso próprio [mundo]. É considerado imoral manter um parceiro "amoroso" para além de um tempo relativamente curto. "Amor" é desejo sexual efêmero, que deve ser satisfeito imediatamente. 
Toma-se o maior cuidado para evitar que você ame demais a qualquer um. Não há nada que se assemelhe a uma aliança cindida; você é condicionado de tal modo que não pode deixar de fazer o que deve. E o que se deve fazer é, em geral, tão agradável, permitese o jogo livre a tantos impulsos naturais, que não há, verdadeiramente, quaisquer tentações a se resistir. ${ }^{111}$

Essa falta de inibição dos desejos leva à paralisia e eventualmente à destruição do self. Se eu não postergo a satisfação do meu desejo (e sou condicionado a desejar apenas o que posso conseguir), eu não tenho conflitos, não tenho dúvidas; nenhuma decisão precisa ser tomada; eu nunca estou sozinho comigo mesmo, porque estou sempre ocupado - seja trabalhando ou me divertindo. Eu não tenho necessidade de estar ciente de mim como sendo eu mesmo [aware of myself as myself], porque estou constantemente absorvido em ter prazer. Eu sou um sistema de desejos e satisfações; eu tenho que trabalhar para realizar meus desejos - e esses mesmos desejos são constantemente estimulados e dirigidos pela máquina econômica. A maioria desses apetites é sintética; até mesmo o apetite sexual não é de modo algum tão "natural" quanto se diz que seja. Ele é, em alguma medida, estimulado artificialmente. E ele precisa ser, se nós quisermos ter pessoas tais como o sistema contemporâneo precisa delas - pessoas que sentem-se "felizes", que não têm conflitos, que são guiadas sem o uso da força.

O princípio, pois, de que o amor é idêntico ao desejo sexual, e a ideia de que a emancipação do homem reside na satisfação completa e sem restrições de seu desejo sexual é, na verdade, parte do cimento que une os homens na fase atual do capitalismo. Ele foi uma ideologia reformista no começo do século; pensar que seja uma teoria radical agora significa não ter aprendido nada com o desenvolvimento da sociedade durante os últimos trinta anos.

111 HUXLEY, A. Brave new world. London: The Vanguard Library, p. 196. [Edição brasileira: Admirável mundo novo. São Paulo: Globo, 2014, p. 117, 120, 264, 283. Fromm cita explicitamente apenas a última página.] 
Eu me dirijo agora à segunda tese de Marcuse: sua crítica do "revisionismo".

Marcuse afirma que os conceitos mais básicos de Freud, como por exemplo a função do inconsciente, "foram redefinidos (por mim) $)^{112}$ de tal maneira que suas conotações explosivas foram quase completamente eliminadas. [...] A psicanálise foi reorientada à psicologia da consciência tradicional, de textura préfreudiana". Marcuse nem mesmo tenta dar sustento a essa crítica. Meu próprio trabalho (e o de Sullivan, e em grande medida o de Horney) está centrado no conflito entre aspirações inconscientes e conscientes. Se alguém assume que o inconsciente é idêntico a aspirações sexuais, pode estar cego o suficiente para presumir que qualquer teoria que não admita que o instinto sexual é a força motriz [humana] desconsidera o inconsciente - mas é preciso uma boa dose de ingenuidade, na melhor das hipóteses, para chegar a essa conclusão. Relacionada a esse ponto é a insistência de Marcuse em que "fatores e relações secundários (entre a pessoa madura e seu ambiente cultural) a dignidade de processos primários", negligenciando assim o impacto da primeira infância, "período formativo do destino universal no indivíduo". Eu não consigo entender como Marcuse pode ter perdido de vista o fato de que o trabalho de Sullivan é quase inteiramente dedicado ao desenvolvimento da infância, e que eu afirmei que o caráter de uma pessoa é predominantemente determinado por sua situação na infância. Eu tentei mostrar em $\mathbf{O}$ medo à liberdade [Escape from freedom] que esse fato, entretanto, não contrasta com o impacto da sociedade sobre o indivíduo, porque a família é “a agência psicológica da sociedade", que tem a função de moldar o caráter da pessoa em crescimento de um modo útil e necessário para o funcionamento contínuo de uma sociedade existente. Marcuse não se refere a um dos conceitos centrais em todos os meus escritos, do artigo de 1932 até o presente - a saber, o de "caráter social". Eu defini o caráter social como o núcleo da estrutura de caráter que é partilhado pela maioria dos membros de uma mesma cultura. Os membros da sociedade e das várias classes ou grupos de

112 [Este acréscimo é do próprio Fromm.] 
status dentro dela têm que se comportar de tal modo que possam funcionar no sentido requerido pelo sistema social. A função do caráter social é canalizar as energias dos membros da sociedade de modo que seu comportamento não seja uma questão de decisão consciente quanto a seguir ou não o padrão social, mas de desejar agir como eles têm que agir, e ao mesmo tempo encontrar gratificação em agir de acordo com os requisitos da cultura. Em outras palavras, a função do caráter social é moldar e canalizar energia humana dentro de uma dada sociedade para o propósito do funcionamento contínuo dessa sociedade.

Mais importante, entretanto, que todas essas distorções ou incompreensões, é o ponto central de Marcuse: o de que falar de amor, integridade, força interior etc., significa falar em um nível ideológico. Apenas o instinto sexual é o sub-estrato da realidade que subjaz à super-estrutura do amor etc. Marcuse alegaria que ódio, destrutividade, sadismo, é uma ideologia? Obviamente não. A única controvérsia que poderia aparecer é a de se [esses fenômenos] são explicados como estando enraizados no instinto sexual, no instinto de morte, ou em outros fatores fundamentais da existência humana. Amor e força interior são, por outro lado, de acordo com Marcuse, apenas ideologias. Seu argumento é o de que na sociedade alienada contemporânea não existe qualquer amor, integridade ou força interior como uma realidade. Ele afirma que a meta do "desenvolvimento ótimo das potencialidades de uma pessoa e a realização de sua individualidade" é "essencialmente inatingível [...] porque a própria civilização estabelecida, em sua estrutura mesma, a nega". Ele segue dizendo que

Pode-se definir "personalidade" e "individualidade" em termos de suas possibilidades dentro da forma estabelecida de civilização, e então sua realização será, para a vasta maioria, equivalente à adaptação bem-sucedida. Ou então se as define em termos de seu conteúdo transcendente, incluindo as suas potencialidades negadas socialmente para além (e abaixo) de sua existência atual: neste caso, a sua realização implicaria a transgressão para além 
da forma estabelecida de civilização e rumo a modos radicalmente novos de "personalidade" e "individualidade", incompatíveis com aqueles prevalecentes. Hoje, isso significaria "curar" o paciente para tornar-se um rebelde ou (o que significa a mesma coisa) um mártir. $\mathrm{O}$ conceito revisionista vacila entre as duas definições. Fromm reaviva todos os valores da ética idealista que o tempo sancionou, como se ninguém jamais tivesse demonstrado suas características repressivas e conformistas. Ele fala da realização produtiva da personalidade, do cuidado, da responsabilidade e do respeito pelos semelhantes, do amor produtivo e da felicidade, como se o homem pudesse de fato praticar tudo isso e ainda permanecer são e cheio de "bem-estar" em uma sociedade que o próprio Fromm descreve como de alienação total, dominada pelas relações mercadológicas [commodity relations of the 'market'].

O que Marcuse está dizendo aqui é que qualquer pessoa que tenha integridade e seja capaz de amor e felicidade, na sociedade capitalista dos dias de hoje, deve tornar-se, ou um mártir, ou insana. Ele mesmo faz reservas mínimas ao falar dessas metas como "essencialmente" inatingíveis, e de sua realização como equivalente à adaptação para a "grande maioria", mas ele não presta atenção nenhuma a essas qualificações importantes. Eu deixo muito claro em minha própria descrição do caráter produtivo que ele é raro em uma sociedade alienada e que ele está em oposição à orientação mercantil, que é a regra. Eu analiso a orientação produtiva como sendo uma [orientação] que transcende o padrão prevalecente, e apenas uma leitura enviesada pode ignorar o fato de que eu enfatizo repetidas vezes que felicidade e amor, tal como eu os defino, não são as mesmas virtudes que aquelas que se denominam amor e felicidade em uma sociedade alienada. Mas tudo isso é muito diferente de dizer que apenas um mártir ou um psicótico pode ter integridade ou amor hoje.

É impressionante que Marcuse negligencie sua própria posição dialética ao ponto de traçar uma imagem em preto e 
branco, e que se esqueça de que a sociedade alienada já desenvolve em si mesma os elementos que a contradizem. Equacionar um rebelde a um mártir na sociedade ocidental capitalista é bem pouco realista, a não ser que alguém seja tão profundamente conformista que ser um rebelde signifique para ele ser um mártir. Se Marcuse estivesse certo, então de fato nós teríamos de chegar à conclusão de que não há espaço algum para amor e felicidade na sociedade capitalista. A única diferença entre o homem médio e o "pensador radical", então, é que o homem médio é um autômato oportunista sem saber disso, enquanto o pensador radical também o é, mas sabendo-o. Na teoria de Marcuse, obviamente a desumanização do homem tem que alcançar a completude, e depois - apenas depois - a liberação pode suceder. Qualquer um que estude as condições para a felicidade e o amor está, de acordo com Marcuse, traindo o pensamento radical. Qualquer um que tente ajudar a si mesmo e aos outros a realizar em alguma medida esses traços - salvo [que seja] um mártir ou um tolo - é uma companhia para o Reverendo [Norman Vincent] Peale. Eu acredito, ao contrário, que estudar as condições para o amor e para a integridade significa descobrir as razões para seu fracasso na sociedade capitalista; que a análise do amor é crítica social; que a tentativa de praticar essas virtudes equivale ao ato de rebelião mais vital. Infelizmente, essa não é apenas uma questão acadêmica. A negligência do fator humano, e a insensibilidade a qualidades morais em figuras políticas, que era tão aparente na atitude de Lenin, é uma das razões para a vitória do stalinismo. O stalinismo é a realização do socialismo, com a exceção de seus objetivos humanos. Como qualquer aperfeiçoamento da situação humana dependerá da mudança simultânea nas esferas econômica, política e caracterológica humana, nenhuma teoria que assuma uma atitude niilista frente ao homem pode ser radical.

Eu concordo com Marcuse: a sociedade capitalista contemporânea é uma sociedade de alienação. Por isso, é uma sociedade em que os objetivos de vida humanistas - os de felicidade e individualidade - raramente se realizam. (Em Psicanálise da sociedade contemporânea [The sane society], que acabou de ser publicado, eu lido com os efeitos da alienação sobre 
o indivíduo). Mas eu discordo completamente da visão de que, em consequência disso, essas qualidades não existem em ninguém; de que analisar sua natureza e as condições para seu desenvolvimento é ideológico, e de que o encorajamento de sua prática significa pregar adaptação. A posição de Marcuse é um exemplo de niilismo humano disfarçado como radicalismo. 
$|60|$

Tradução

\section{Uma réplica a Erich Fromm ${ }^{113}$}

Herbert Marcuse

Na tentativa de refutar o argumento de meu artigo "As implicações sociais do 'revisionismo' freudiano" (Dissent, verão de 1955), Erich Fromm construiu uma tese que eu não afirmei. ${ }^{114}$ Embora sua interpretação equivocada possa dever-se em grande medida ao fato de que meu livro, Eros e civilização, ao qual o artigo referia-se especificamente, ainda não havia sido publicado, eu sinto que algumas correções são devidas.

1. Fromm atribui a Freud, ou à minha reafirmação da teoria freudiana, as seguintes noções:

a) a de que felicidade é satisfação do instinto sexual, "especificamente do desejo de livre acesso a todas as fêmeas disponíveis";

113 Tradução de Matheus Romanetto. Com a permissão do executor testamentário do Patrimônio Literário de Herbert Marcuse, Peter Marcuse - cuja permissão se exige para qualquer publicação futura. Material suplementar produzido a partir de obras de Herbert Marcuse não antes publicadas, muito do que agora se encontra nos Arquivos da Universidade Goethe de Frankfurt am Main, está sendo publicado pela Editora Routledge, da Inglaterra, em uma série de seus volumes editada por Douglas Kellner, bem como em uma série alemã editada por Peter-Erwin Jansen e publicada pela Editora zu Klampen, da Alemanha. Todos os direitos para publicações futuras são retidos pelo Patrimônio. [With permission of the Literary Estate of Herbert Marcuse, Peter Marcuse, Executor, whose permission is required for any further publication. Supplementary material from previously unpublished work of Herbert Marcuse, much now in the Archives of the Goethe University in Frankfurt/Main, is being published by Routledge Publishers, England, in a six-volume series edited by Douglas Kellner, and in a German series edited by Peter-Erwin Jansen published by zu Klampen Verlag, Germany. All rights to further publication are retained by the Estate.]

114 [O texto dá aqui a referência bibliográfica do texto de Fromm, que não reproduzimos por julgar supérflua]. 
b) a de que o amor é em sua "essência", ou é "idêntico a", desejo sexual; e

c) as de que o homem tem um "desejo inerente por satisfação sexual ilimitada" e de que "a emancipação do homem reside na satisfação completa e sem restrições de seu desejo sexual".

Longe de identificar felicidade com "satisfação sem restrições" do desejo sexual, Freud sustentou que a "irrestrita liberdade sexual" resulta "desde o início" em uma falta de satisfação plena, e que o "valor" das necessidades eróticas "cai instantaneamente, tão logo a satisfação se torna prontamente acessível". Ele considerou a "estranha possibilidade" de que "algo na natureza do instinto sexual não seja favorável ao alcance da plena satisfação". ${ }^{115}$

Freud não definiu a "essência" do amor como desejo sexual, mas como a inibição e sublimação do desejo sexual pela ternura e pela afeição, e ele viu nessa "fusão" uma das maiores conquistas da civilização. Consequentemente, Freud não poderia ter a "ideia" (e tampouco eu a tive) de que "a emancipação do homem reside na satisfação completa e sem restrições de seu desejo sexual" (embora eu não concorde com Fromm [quando afirma] que essa ideia é parte do "cimento que une os homens na fase atual do capitalismo").

2. Freud de fato reconheceu, entretanto, que mesmo os mais elevados valores da civilização, à medida que contêm sexualidade inibida e desviada na meta, inevitavelmente pressupõem e perpetuam a não-liberdade e a supressão. Fromm conclui que Freud não deixa esperança para "nenhuma melhoria fundamental da sociedade" e que a sua teoria não é uma "crítica radical da sociedade alienada" porque ela considera a "alienação" como o pré-requisito necessário de toda civilização. Além disso, Fromm enfatiza que Freud não ofereceu uma crítica da "estrutura socioeconômica" da sociedade contemporânea. Neste ponto, eu

\footnotetext{
115 Collected papers, vol. IV, loc. cit., p. 213-4.; negrito acrescentado por Marcuse. [Edição brasileira: Sobre a mais comum depreciação na vida amorosa, loc. cit., p. 359-60. Edição alemã: Über die allgemeinste Erniedrigung des Liebeslebens, loc. cit., p. 88-9.]
} 
concordo, e eu não o afirmei. Na primeira página de meu artigo, eu enfatizei o grau em que a psicanálise "estava ainda comprometida com a sociedade cujos segredos ela revelava". Quando eu falei das implicações críticas radicais da teoria freudiana, eu me referi àqueles aspectos seus que elucidam a profundidade dos controles repressivos sobre a "natureza" do homem - controles que a sociedade contemporânea partilha com as formas históricas precedentes de civilização repressiva.

Isso pode não ser suficiente, mas parece-me muito mais crítico do que acusar alguns aspectos secundários e "excessos" de "alienação", enquanto se preservam e até mesmo se fortalecem as suas raízes. Fromm, que acusa Freud de não criticar o capitalismo, escreve: a alienação do trabalhador em relação a seu trabalho
só pode ser eliminada se ele não for empregado pelo capital, se ele não for o objeto de comando, mas se ele se tornar um sujeito responsável que emprega o capital. O ponto principal não é, aqui, a propriedade dos meios de produção, mas a participação na gerência e na tomada de decisões. ${ }^{116}$

Ele pensa que o princípio de coadministração significa uma "séria restrição" dos direitos de propriedade. O proprietário ou os proprietários têm direito a uma taxa de lucro razoável sobre o seu investimento de capital, mas não ao "comando irrestrito sobre os homens que o seu capital pode contratar". ${ }^{117}$ Terá o empresário, que emprega o trabalho assalariado livre, alguma vez tido [de fato] tal "comando irrestrito"?

Fromm vê na "participação dos trabalhadores" um meio para "humanizar" o trabalho, para estabelecer uma relação "significativa" entre o trabalhador, seu trabalho e seus

116 The sane society. New York: Rinehart and Co., 1955, p. 323, itálicos de Fromm. [Edição brasileira: Psicanálise da sociedade contemporânea, loc. cit., p. 310-11. Marcuse dá o título do livro sem acrescentar a edição.]

${ }^{117}$ Ibid., p. 324 [Edição brasileira: Ibid., p. 312.] 
companheiros, e ele cita o caso de "uma das sete maiores fábricas de relógios" na França, onde um tipo de trabalho comunitário foi realizado. ${ }^{118}$ Os próprios trabalhadores elaboraram um "decálogo", que inclui, em acréscimo a alguns dos Dez Mandamentos: "tu deverás ganhar teu pão com o suor de teu rosto". Se são esses os elementos que "contradizem" a alienação, então meu argumento contra Fromm de fato colapsa em um ponto decisivo.

3. Fromm expressa "espanto" [com o fato de que] eu deveria cometer o erro de denominar radical uma teoria (a teoria dos instintos de Freud) que está "inteiramente no mesmo espírito do que a do materialismo burguês do século XIX". O que têm Eros (para o qual Freud faz referência - e não acidentalmente - a Platão) e o Instinto de Morte, o que têm o Princípio do Nirvana e "a natureza conservadora comum dos instintos" a ver com o materialismo burguês do século XIX? Essa é a dimensão profunda última da teoria freudiana sobre a qual o meu argumento baseou-se e é essa dimensão de profundidade que Fromm descarta (com Horney e Sullivan). Essa mutilação, juntamente à redução da teoria da libido, exigiu a regressão da psicanálise revisionista à psicologia da consciência pré-freudiana. Fromm protesta e demanda evidências. Praticamente todas as páginas de todos os livros que ele escreveu desde $\mathbf{O}$ medo à liberdade [Escape from freedom] são evidência. Caso eu precise mencionar questões específicas: tomemos sua reinterpretação do complexo de Édipo, ou sua análise das neuroses em termos de um "problema moral". A redução revisionista exige também o deslocamento de ênfase da psique pré-individual à "personalidade madura". Novamente, Fromm protesta e aponta o fato de que o trabalho de Sullivan está quase totalmente voltado ao "desenvolvimento da infância", e que em sua própria psicologia, "o caráter de uma pessoa é predominantemente determinado por sua situação na infância". Mas o desenvolvimento infantil pertence ao domínio de toda psicologia da consciência, de todo especialista em relações humanas, e o tratamento que Sullivan lhe

118 [Trata-se da "Communauté Boimondau", que foi fundada por Marcel Barbu, e permaneceu organizada entre 1941 e 1971 na França.] 
concede, em minha opinião, não é essencialmente diferente de suas apresentações mais antigas ao nível superficial das "relações interpessoais". A análise do próprio Fromm dos estágios iniciais do desenvolvimento do caráter foi crescentemente purificada das forças instintuais explosivas ligadas à "herança arcaica" do homem e à luta mortal contra a supressão. Revelar as implicações dessa luta (e portanto as condições reais para a "emancipação do homem") foi a grande preocupação da psicologia profunda de Freud. Ela não se conserva [simplesmente] ao se prestar atenção ao "conflito entre aspirações inconscientes e conscientes", [mas] depende [também] do conteúdo e da dinâmica do inconsciente.

4. Fromm acusa-me de negligenciar o "fator humano" e de "insensibilidade às qualidades morais". Ele afirma como sendo minha "tese" que "qualquer um que estude as condições para a felicidade e o amor está traindo o pensamento radical". Minha tese é, ao contrário, que Fromm (e os demais revisionistas) não estudam realmente as condições para "a felicidade e o amor". Eu digo explicitamente em meu artigo (p. 22) que não são esses valores que são espúrios, "mas [sim] o contexto em que eles são definidos e proclamados". Eles são definidos por Fromm em termos de pensamento positivo, que deixa o negativo onde está - predominando sobre a existência humana. Fromm sustenta que seu conceito de "amor produtivo" rejeita a adaptação a uma "sociedade alienada". É precisamente isso que eu questiono; eu penso que seus conceitos partilham da alienação. As sugestões práticas que ele fornece como a "via para a sanidade" em seu novo livro (uma delas foi citada acima) são, em minha opinião, um exemplo perfeito de como propostas para um funcionamento mais suave da sociedade estabelecida podem ser confundidas com as noções que transcendem essa sociedade. Não há nada de errado com psicologia industrial e administração científica melhores e em maior quantidade, mas há algo tremendamente errado em apresentá-las como humanismo não-conformista. Fromm lembra-me de que "a sociedade alienada desenvolve em si mesma os elementos que a contradizem". Ela o faz, mas eu discordo de Fromm acerca de onde estão esses elementos, e quais 
são eles: muito do que ele denomina alienação é para mim a força que supera a alienação, e o que ele denomina o positivo é para mim ainda o negativo. "Niilismo", como a acusação de condições desumanas, pode ser uma atitude verdadeiramente humanista parte da Grande Recusa em jogar o jogo, a comprometer-se com o mau "positivo". Nesse sentido, eu aceito a designação de Fromm de minha posição como "niilismo humano". 


\section{Uma tréplica ${ }^{119}$}

Erich Fromm

Eu não julgaria necessário gastar a paciência dos leitores da Dissent com uma tréplica à réplica [que] Marcuse [dirigiu] a mim, se fosse apenas para responder ao seu argumento ou sua interpretação adicional de Psicanálise da sociedade contemporânea [The sane society]. Quanto àquele argumento, ele não acrescenta muito ao seu artigo original. Quanto a esta interpretação, eu deverei deixar que qualquer leitor de Psicanálise da sociedade contemporânea julgue se o livro toma o partido da "psicologia industrial e administração científica melhores e em maior quantidade".

$\mathrm{Eu}$ desejo de fato responder Marcuse, entretanto, com respeito à sua interpretação de Freud, já que os trabalhos desse autor, especialmente o artigo ao qual Marcuse se refere, não são tão facilmente acessíveis à maioria dos leitores.

Marcuse diz que é errôneo atribuir a Freud a visão:

a) de que felicidade é satisfação do instinto sexual,

b) de que amor é em sua essência desejo sexual, e

c) de que o homem tem um desejo inerente por satisfação sexual ilimitada.

Até aqui, Marcuse. Agora, Freud:

ad a) "O homem, tendo descoberto pela experiência que o amor sexual (genital) proporcionava a ele sua maior satisfação, de modo que ele se tornou para ele de fato um protótipo para toda a felicidade, deve ter sido impelido a partir de então a continuar a procurar sua felicidade na trilha das relações sexuais, a fazer do erotismo genital o ponto central de sua vida" ${ }^{120} \mathrm{Cf}$. também

\footnotetext{
119 Tradução de Matheus Romanetto. Copyright c 1956 by Erich Fromm; Copyright c 2019 by Erich Fromm Estate (fromm-estate@fromm-online.com).
}

${ }^{120}$ Civilization and its discontents, loc. cit., p. 69, itálicos meus. [Edição bra- 
a afirmação de Freud de que o homem primitivo "não conhecia quaisquer restrições aos instintos", de que podia gozar sua felicidade mais do que o homem civilizado, mas devido à agressão mútua, não por muito tempo. ${ }^{121}$

$a d$ b) "O amor com uma meta inibida foi, na origem, amor plenamente sensual, e na mente inconsciente dos homens ainda o é". ${ }^{122}$

ad c) "Suponha-se que os direitos pessoais aos bens materiais sejam eliminados; [então] subsistem ainda prerrogativas $\mathrm{n}[\mathrm{o}$ âmbito d]as relações sexuais, que devem trazer à tona o mais forte rancor e a mais violenta inimizade entre homens e mulheres que, de outro modo, são iguais". ${ }^{123}$

Todas essas citações são retiradas daquele trabalho de Freud, publicado pela primeira vez em 1930, que lida de maneira mais completa e direta com o problema do sexo, da felicidade e da sociedade. Marcuse, em sua resposta, ignora esse livro completamente, e cita o artigo de Freud "Sobre a mais comum

sileira: O mal-estar na civilização, loc. cit., p. 64. Edição alemã: Das Unbehagen in der Kultur, loc. cit., p. 460. A versão brasileira suprime "Erfahrung", que aparece em inglês como "experience" (experiência). "Mensch" torna-se "indivíduo" em português, e "man" (homem) em inglês. De "Befriedigungserlebnisse" a tradução brasileira aproxima-se de uma versão mais literal com "vivências de satisfação", enquanto o inglês diz apenas "satisfaction" (satisfação). Finalmente, "Glücksbefriedigung"'- literalmente, satisfação da felicidade - torna-se "satisfação vital" em português, e mais simplesmente "happiness" (felicidade) em inglês.]

${ }^{121}$ Cf. Civilization and its discontents, loc. cit., p. 91-2. [Edição brasileira: $\mathbf{O}$ mal-estar na civilização, loc. cit., p. 82. Edição alemã: Das Unbehagen in der Kultur, loc. cit., p. 474.]

${ }^{122}$ Civilization and its discontents, loc. cit., p. 71, itálicos meus. [Edição brasileira: $\mathbf{O}$ mal-estar na civilização, loc. cit., p. 66. Edição alemã: Das Unbehagen in der Kultur, loc. cit., p. 462. O que, no inglês de Fromm, aparece como "a mente inconsciente dos homens" é, no original, alemão "Unbewußten des Menschen" - inconsciente do ser humano.]

${ }^{123}$ Cf. Civilization and its discontents, p. 89. [Edição brasileira: O mal-estar na civilização, loc. cit., p. 80. O original encontra-se já citado anteriormente.] 
depreciação na vida amorosa", publicado pela primeira vez em 1912. É verdade que Freud escreve nesse artigo que "a importância de um desejo instintual é aumentada mentalmente com a sua frustração", e "eu acho que devemos considerar a possibilidade de que algo na natureza do próprio instinto sexual seja desfavorável à conquista da gratificação absoluta" ${ }^{124}$ Infelizmente, Marcuse deixa de mencionar duas coisas: primeiro, que no parágrafo final do mesmo artigo, Freud afirma sua tese da incompatibilidade básica entre instinto sexual e as demandas da cultura, precisamente como eu descrevi em minha réplica a Marcuse. Freud afirma que porque a cultura impede que o homem obtenha prazer sexual plenamente satisfatório, ele põe sua energia a outros usos - isto é, a usos culturais. Quanto à afirmação de Freud de que há algo na natureza do instinto sexual que é desfavorável à conquista da satisfação sexual, Marcuse omite o que Freud quis dizer com isso, embora Freud seja muito claro quanto a isso no artigo de 1912, e especialmente em $\mathbf{O}$ mal-estar na civilização, em uma nota de rodapé na página 78 [ed. brasileira: p. 72]. A ideia de Freud é que a satisfação plena do instinto sexual é possível apenas se seus componentes sádicos e coprofílicos forem satisfeitos. Isso não é possível no amor matrimonial, porque um homem que respeita sua esposa necessariamente tem que frustrar esses desejos; mas - afirma Freud em $\mathbf{O}$ mal-estar na civilização -, a frustração desses desejos é necessária até mesmo nos primórdios da cultura, "como consequência da adoção da postura ereta pelo homem e da depreciação do sentido do olfato". ${ }^{125}$ Nessa visão, a repressão da satisfação sexual plena, e portanto a frustração da felicidade, já é

124 [Edição brasileira: Sobre a mais comum depreciação na vida amorosa (contribuições à psicologia do amor II), loc. cit., p. 360. Fromm não fornece a página das citações. O original encontra-se citado já anteriormente, acrescentando-se também agora o seguinte trecho: "die psychische Bedeutung eines Triebes mit seiner Versagung steigt". A versão inglesa traduz "Trieb", geralmente apenas "instinto", por "instinctual desire", desejo instintual.]

125 [Edição brasileira: O mal-estar na civilização, loc. cit., p. 70. Edição alemã: Das Unbehagen in der Kultur, loc. cit., p. 466.] 
exigida pelos começos mais rudimentares da civilização humana. Pode-se ver que essa opinião de Freud aponta na mesma direção que eu tinha indicado. A tese de Freud é a de que o homem primitivo goza de um montante maior de felicidade do que o homem civilizado, porque ele ainda não está sujeito a tanta repressão sexual quanto esse último, mas que mesmo nos primórdios mais remotos da existência humana, já havia necessidade de um certo montante de repressão sexual que prevenia o homem de atingir a felicidade completa. O ponto de Freud não é duvidar de que a satisfação genital seja a fonte da felicidade, mas [sim indicar] que o homem nunca pode ser tão feliz, pois qualquer tipo de civilização o força a frustrar a satisfação plena de seus desejos genitais, especialmente os componentes sádicos e coprofílicos.

\section{Referências bibliográficas}

\section{Fontes primárias}

MARCUSE, H. The social implications of Freudian 'revisionism'. Dissent: a quarterly of socialist opinion, v. 2, n. 3, 1955, pp. 221-240 MARCUSE, H. Epilogue: critique of Neo-Freudian revisionism. in: Eros and civilization: a philosophical inquiry into Freud. Boston: Beacon Press, 1974. [Edição brasileira: Eros e civilização: uma interpretação filosófica do pensamento de Freud. Rio de Janeiro: LTC, 1999.]

FROMM, E. The human implications of instinctivistic 'radicalism': a reply to Herbert Marcuse. Dissent: a quarterly of socialist opinion, v. 2, n. 4, 1955, pp. 342-349.

MARCUSE, H. A reply to Erich Fromm. Dissent: a quarterly of socialist opinion, v. 3, n. 1, 1956, pp. 79-81.

FROMM, E. A counter-rebuttal. Dissent: a quarterly of socialist opinion, v. 3, n. 1, 1956, pp. 81-83. 


\section{Citações de Fromm e Marcuse}

BEAGLEHOLE, E. Interpersonal theory and social psychology. in: Patrick Mullahy (ed.), A study in interpersonal relations. New York: Hermitage Press, 1950.

BREUER, J; FREUD, S. Studies in hysteria. New York: Nervous and Mental Disease Monograph no. 61, 1936 [1895]. [Edição brasileira: Estudos sobre histeria. São Paulo: Companhia das Letras, 2016. Edição alemã: Studien über Hysterie. in: Gesammelte Werke, Band I. London: Imago Publishing, 1952.]

FREUD, S. The most prevalent form of degradation in erotic life. in: Collected papers, vol. IV. London: Hogarth Press, 1950 [1912]. [Edição brasileira: Sobre a mais comum depreciação na vida amorosa (contribuições à vida amorosa II). in: Obras completas, volume 9. São Paulo: Companhia das Letras, 2013. Edição alemã: Über die allgemeinste Erniedrigung des Liebeslebens. in: Gesammelte Werke, Band VIII. London: Imago Publishing, 1955.]

FREUD, S. A general introduction to psyschoanalysis. New York: Garden City Publishing Co., 1943 [1916-17]. [Edição brasileira: Conferências introdutórias à psicanálise. in: Obras completas, volume 13. São Paulo: Companhia das Letras, 2014.]

FREUD, S. The loss of reality in neurosis and psychosis. in: Collected papers, vol. II. London: Hogarth Press, 1950 [1924]. [Edição brasileira: A perda da realidade na neurose e na psicose. in: Obras completas, volume 16. São Paulo: Companhia das Letras, 2011. Edição alemã: Der Realitätsverlust bei Neurose und Psychose. in: Gesammelte Werke, Band XIII. London: Imago Publishing, 1940.]

FREUD, S. Civilization and its discontents. London: Hogarth Press, 1949 [1929-30]. [Edição brasileira: O mal-estar na civilização. in: Obras completas, volume 18. São Paulo: Companhia das Letras, 2010. Edição alemã: Das Unbehagen in der Kultur, in: Gesammelte Werke, Band XIV. Londres: Imago Publishing, 1955.] 
FREUD, S. New introductory lectures. New York: W. W. Norton, 1933. [Edição brasileira: Novas conferências introdutórias à psicanálise. in: Obras completas, volume 18. São Paulo: Companhia das Letras, 2010.]

FROMM, E. Über Methode und Aufgabe einer analytischen Sozialpsychologie. Zeitschrift für Sozialforschung, v. I, 1932. [Edição brasileira: Método e função de uma psicologia social analítica. in: A crise da psicanálise. Rio de Janeiro: Zahar Editores, 1977.]

FROMM, E. Das sozialpsychologische Bedeutung der Mutterrechtstheorie. Zeitschrift für Sozialforschung, v. III, 1934. [Edição brasileira: A teoria do direito materno e sua relevância para a psicologia social. in: A crise da psicanálise. Rio de Janeiro: Zahar Editores, 1977.]

FROMM, E. Die gesellschaftliche Bedingtheit der psychoanalytischen Therapie. Zeitschrift für Sozialforschung, v. IV, 1935.

FROMM, E. Escape from freedom, New York: Rinehart and Co., 1941. [Edição brasileira: $\mathbf{O}$ medo à liberdade. Rio de Janeiro: Zahar Editores, 1981.]

FROMM, E. Man for himself. New York: Rinehart and Co., 1947. [Edição brasileira: Análise do homem. Rio de Janeiro: Zahar Editores.]

FROMM, E. Psychoanalysis and religion, New Haven: Yale University Press 1950. [Edição brasileira: Psicanálise e religião. Rio de Janeiro: Livro Íbero-Americano Ltda, 1959.]

FROMM, E. The forgotten language. New York: Rinehart, 1951. [Edição brasiileira: A linguagem esquecida. Rio de Janeiro: Zahar Editores, 1969.]

FROMM, E. The sane society. New York: Rinehart and Co., 1955. [Edição brasileira: Psicanálise da sociedade contemporânea. Rio de Janeiro: Zahar Editores, 1974.] 
GLOVER, E. Freud or Jung. New York: W. W. Norton, 1950.

HORNEY, K. The neurotic personality of our time. New York: W. W. Norton and Co., 1937. [Edição brasileira: A personalidade neurótica de nosso tempo. Rio de Janeiro: Editora Civilização Brasileira S.A., 1959.]

HORNEY, K. New ways in psychoanalysis. New York: W. W. Norton, 1939 [Edição brasileira: Novos rumos na psicanálise. Rio de Janeiro: Editora Civilização Brasileira S.A., 1966.]

HUXLEY, A. Brave new world. London: The Vanguard Library, 1952 [1932]. [Edição brasileira: Admirável mundo novo. São Paulo: Globo, 2014.]

LYND, H. Resenha de "Concepts of Modern Psychiatry", de H. S. Sullivan. The Nation, 15 de janeiro de 1949.

MULLAHY, P. Introduction. A study of interpersonal relations. New York: Hermitage Press, 1950 [1949].

REICH, W. Einbruch der Sexualmoral: zur Geschichte der sexuellen Ökonomie. Kopenhagen: Verlag für Sexualpolitik, 1935 [1931]. [Edição portuguesa: A irrupção da moral sexual repressiva. Porto: Escorpião, 1974.]

SULLIVAN, H. Conceptions of modern psychiatry. Washington: William Alanson White Psychiatric Foundation, 1947.

SULLIVAN, H. The interpersonal theory of psychiatry. New York: W. W. Norton and Co., 1953.

THOMPSON, C. Psychoanalysis: evolution and development. New York: Hermitage House, Inc., 1951 [1950]. [Edição brasileira: Evolução da psicanálise. Rio de Janeiro: Zahar Editores, 1969.]

\section{Comentários da tradução}

FREUD, S. O futuro de uma ilusão. in: Obras completas, volume 17. São Paulo: Companhia das Letras, 2014 [1927]. 
FROMM, E. The revolution of hope: toward a humanized technology. New York: Bantam Books, 1968. [Edição brasileira: A revolução da esperança. Rio de Janeiro: Zahar Editores, 1984.]

FROMM, E. Marx's concept of man. New York: Bloomsbury, 2013 [1961]. [Edição brasileira: Conceito marxista de homem. Rio de Janeiro: Zahar Editores, 1983.]

FROMM, E. The crisis of psychoanalysis. in: The crisis of psychoanalysis: essays on Freud, Marx, and social psychology. New York: Holt, Rinehart and Winston, 1970. [Edição brasileira: A crise da psicanálise. Rio de Janeiro: Zahar Editores, 1977.]

FROMM, E. The anatomy of human destructiveness. New York: Henry Holt and Co., 1992 [1973]. [Edição brasileira: A anatomia da destrutividade humana. Rio de Janeiro: Zahar Editores, 1975.]

FROMM, E. The alleged radicalism of Herbert Marcuse. in: The revision of psychoanalysis. Boulder: Westview Press, 1990. [Edição brasileira: O suposto radicalismo de Herbert Marcuse. in: A descoberta do inconsciente social: contribuição ao redirecionamento da psicanálise. São Paulo: Editora Manole Ltda., 1992.]

JONES, E. The life and work of Sigmund Freud. New York: Basic Books, 1981 [1953-7]. [Edição brasileira: A vida e a obra de Sigmund Freud. Rio de Janeiro: Imago, 1989. 3 volumes.]

MARCUSE, H. Theory and therapy in Freud. in: Collected papers, vol. 5. New York: Routledge, 2011 [1957]. [Edição brasileira: Teoria e terapia em Freud. Educação e filosofia, v. 32, n. 64.]

MARCUSE, H. The obsolescence of psychoanalysis. in: Collected papers, vol. 5. New York: Routledge, 2011 [1963]. [Edição brasileira: A obsolescência da psicanálise. in: Cultura e sociedade, vol. 2. São Paulo: Paz e Terra, 1989.]

MARCUSE, H. One-dimensional man. Routledge, 2006 [1964]. [Edição brasileira: $\mathbf{O}$ homem unidimensional. São Paulo: Edipro, 2015.] 
MENNINGER, K. Man against himself. New York: Harcourt, Brace \& World, Inc., 1938. [Edição brasileira: Eros e Tanatos: o homem contra si próprio. São Paulo: Ibrasa, 1970.]

PEALE, N. The power of positive thinking. New York: Simon and Schuster, 2005 [1952]. [Edição brasileira: O poder do pensamento positivo. São Paulo: Cultrix, 2016.]

\section{História e desdobramentos do debate Fromm-Marcuse}

ADORNO, T. A psicanálise revisada. in: Ensaios de psicologia social e psicanálise. São Paulo: Editora Unesp, 2015. [Edição alemã: Das revidierte Psychoanalyse. Gesammelte Schriften, Band 8.1. Frankfurt: Surkhamp Verlag, 2003.]

ADORNO, T. Social science and sociological tendencies in psychoanalysis. in: W. Bock. Dialektische Psychologie: Adornos Rezeption der Pscyhoanalyse. Berlin: Springer, 2018.

BURSTON, D. Oedipus, instinct, and the unconscious in the Fromm-Marcuse debate. in: The legacy of Erich Fromm. London: Harvard Universtiy Press, 1991.

BUZBY, Amy. New foundations for resistance: the MarcuseFromm debate revisited. in: Subterranean politics and Freud's legacy. New York: Palgrave Macmillan.

DUNCAN, C. Love and its refusal: love, historical memory, and the meaning of perversion in the Fromm-Marcuse feud. Tese de mestrado, Austin, University of Texas, 2013.

JACOBY, R. Social amnesia: a critique of contemporary psychology from Adler to Laing. New York: Transaction Publishers, 1997. [Edição brasileira: Amnésia social: uma crítica da psicologia conformista, de Adler a Laing. Rio de Janeiro: Zahar Editores, 1977.]

KELLNER, D.; PIERCE, C.; LEWIS, T. Introduction: Hebert Marcuse, philosphy, psychoanalysis, and emancipation. in: 
Herbert Marcuse. Collected papers, vol. 5. New York: Routledge, 2011. Veja-se também o comentário dos editores na página 101.

McLAUGHLIN, N. The Fromm-Marcuse debate and the future of critical theory. in: The Palgrave handbook of critical theory. New York: Palgrave Macmillan, 2017.

RICKERT, J. The Fromm-Marcuse debate revisited. Theory and society, v. 15, n. 3, 1986, pp. 351-400. 